Development of an Advanced, Continuous Mild Gasification Process for the Production of Co-Products, Task 4.8: Decontamination and Disassembly of the Mild Gasification Process Research Unit and Disposal of Co-Products

\title{
Topical Report
}

Robert O. Ness, Jr.

Yufu Li

Marlys Heidt

September 1992

Work Performed Under Contract No.: DE-AC21-87MC24267

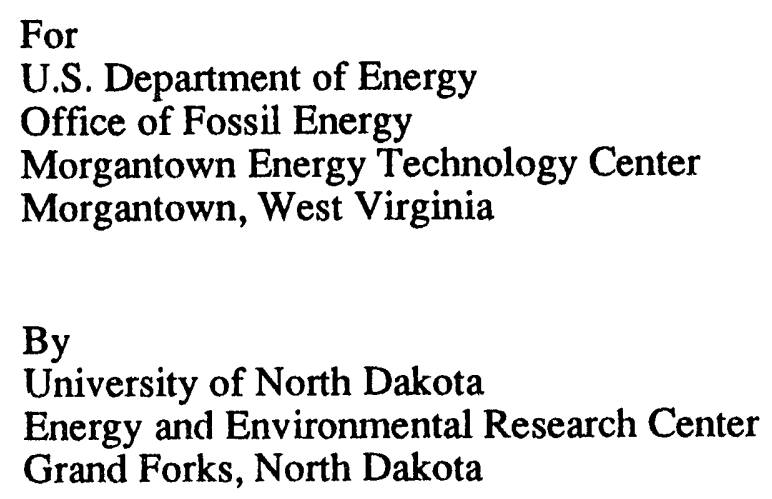

For

U.S. Department of Energy

Office of Fossil Energy

Morgantown Energy Technology Center

Morgantown, West Virginia

By

University of North Dakota

Energy and Environmental Research Center

Grand Forks, North Dakota

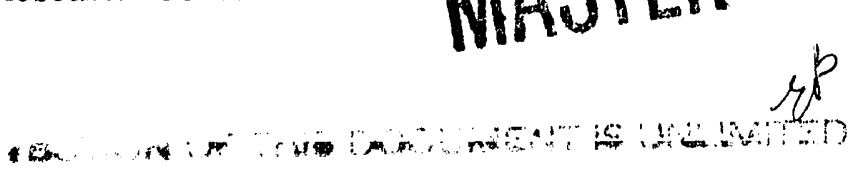




\section{DISCLAIMER}

This report was prepared as an account of work sponsored by an agency of the United States Government. Neither the United States Government nor any agency thereof, nor any of their employees makes any warranty, express or implied, or assumes any legal liability or responsibility for the accuracy, completeness or usefulness of any information, apparatus, product, or process disclosed, or represents that its use would not infringe privately owned rights. Reference herein to any specific commercial product, process, or service by trade name, trademark, manufacturer, or otherwise, does not necessarily constitute or imply its endorsement, recommendation, or favoring by the United States Government or any agency thereof. The views and opinions of authors expressed herein do not necessarily state or reflect those of the United States Government or any agency thereof.

This report has been reproduced directly from the best available copy.

Available to DOE and DOE contractors from the Office of Scientific and Technical Information, P.O. Box 62, Oak Ridge, TN 37831; prices available from (615)576-8401, FTS 626-8401.

Available to the public from the National Technical Information Service, U.S. Department of Commerce, 5285 Port Royal Rd., Springfield, VA 22161. 
Development of an Advanced, Continuous Mild Gasification Process for the Production of Co-Products, Task 4.8: Decontamination and Disassembly of the Mild Gasification . Process Research Unit and Disposal of Co-Products

\author{
Topical Report
}

Robert O. Ness, Jr.

Yufu Li

Marlys Heidt

Work Performed Under Contract No.: DE-AC21-87MC24267

\author{
For \\ U.S. Department of Energy \\ Office of Fossil Energy \\ Morgantown Energy Technology Center \\ P.O. Box 880 \\ Morgantown, West Virginia 26507-0880
}

\author{
By \\ University of North Dakota \\ Energy and Environmental Research Center \\ Box 8213 \\ University Station \\ Grand Forks, North Dakota 58202
}

September 1992 


\section{TABLE OF CONTENTS}

Page

LIST OF FIGURES $\ldots \ldots \ldots \ldots \ldots \ldots \ldots \ldots \ldots \ldots \ldots \ldots \ldots \ldots \ldots \ldots \ldots$ iii

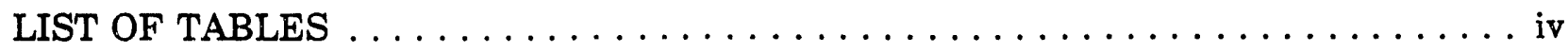

1.0 INTRODUCTION $\ldots \ldots \ldots \ldots \ldots \ldots \ldots \ldots \ldots \ldots \ldots \ldots \ldots \ldots \ldots$

2.0 DESCRIPTION OF THE CONTINUOUS FLUIDIZED-BED REACTOR (CFBR), PROCESS RESEARCH UNIT (PRU), AND CO-PRODUCTS $\ldots \ldots \ldots \ldots \ldots 2$

2.1 Mild Gasification CFBR Description $\ldots \ldots \ldots \ldots \ldots \ldots \ldots \ldots \ldots \ldots$

2.1.1 Process Description ........................ 2

2.1.2 Coal Feed System ......................... 2

2.1.3 Mild Gasification Reactor $\ldots \ldots \ldots \ldots \ldots \ldots \ldots \ldots \ldots \ldots 5$

2.1.4 Preheat System ........................ 5

2.1.5 Gas Quench and Liquid Separation $\ldots \ldots \ldots \ldots \ldots \ldots \ldots \ldots$

2.2 Mild Gasification PRU Description $\ldots \ldots \ldots \ldots \ldots \ldots \ldots \ldots \ldots$

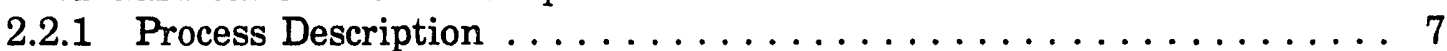

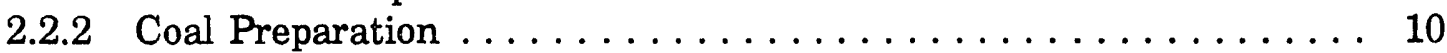

2.2 .3 Utility Requirements $\ldots \ldots \ldots \ldots \ldots \ldots \ldots \ldots \ldots \ldots$

2.2.4 Carbonizer ............................. 10

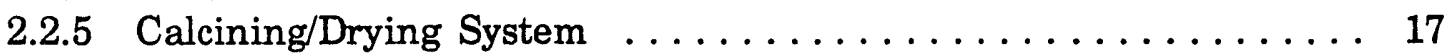

2.2.6 Gas Quench and Liquid Separation ............... 17

2.2.7 Waste Treatment and Phenol Recovery .............. 23

2.3 Characterization of the Co-Products from the CFBR and PRU ....... 33

2.3.1 Characterization of CFBR Co-Products $\ldots \ldots \ldots \ldots \ldots \ldots \ldots, 33$

2.3.1.1 Characterization of CFBR Char ................ 33

2.3.1.2 Characterization of CFBR Liquids ............... 33

2.3.2 Characterization of PRU Co-Products $\ldots \ldots \ldots \ldots \ldots \ldots \ldots . \ldots \ldots$

2.3.2.1 Characterization of PRU Char ................. 37

2.3.2.2 Characterization of PRU Liquids $\ldots \ldots \ldots \ldots \ldots \ldots \ldots \ldots . \ldots \ldots$

2.3.2.3 Gas Characterization ..................... 38

3.0 DECONTAMINATION AND DISASSEMBLY OF THE CFBR AND PRU . . . . 39

3.1 Decontamination and Disassembly of the CFBR $\ldots \ldots \ldots \ldots \ldots \ldots 39$

3.2 Decontamination and Disassembly of the PRU . . . . . . . . . . . 39

4.0 DISPOSAL OF CO-PRODUCTS $\ldots \ldots \ldots \ldots \ldots \ldots \ldots \ldots \ldots \ldots \ldots \ldots$

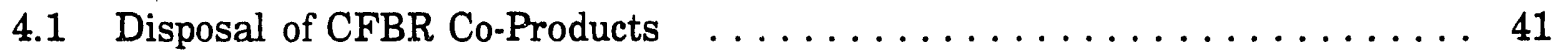

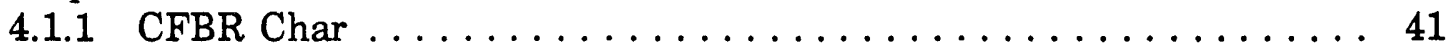

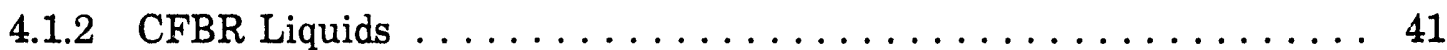

4.2 Disposal of PRU Co-Products $\ldots \ldots \ldots \ldots \ldots \ldots \ldots \ldots \ldots \ldots \ldots$

4.2.1 PRU Char ..............................41

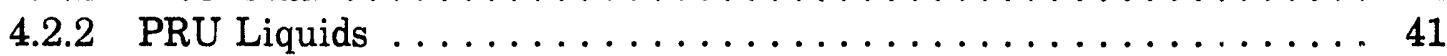

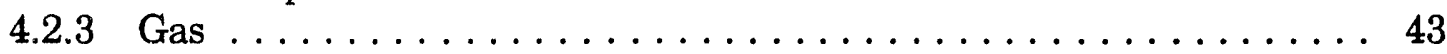


TABLE OF CONTENTS (continued)

Page

5.0 COST AND SCHEDULE OF DECONTAMINATION, DISASSEMBLY, AND

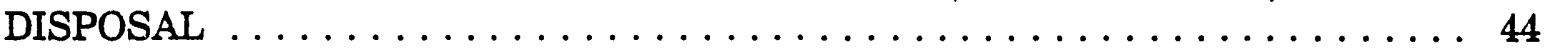

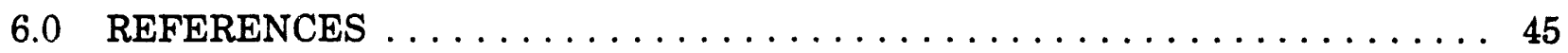

APPENDIX A: PRU MILD GASIFICATION SYSTEM EQUIPMENT LIST . . . . . A A-1

APPENDIX B: WASTEWATER TREATMENT APPROVAL DOCUMENT FROM THE DEPARTMENT OF WATER AND WASTEWATER, CITY OF GRAND FORKS, NORTH DAKOTA $\ldots \ldots \ldots \ldots \ldots \ldots \ldots$ B-1

APPENDIX C: PRU FLARE REJECT GAS APPROVAL DOCUMEN'T FROM THE NORTH DAKOTA STATE HEALTH DEPARTMENT . . . . . . C.1

APPENDIX D: ORGANIC CONDENSABLE APPROVAL DOCUMENT FROM THE NORTH DAKOTA STATE HEALTH DEPARTMENT $\ldots \ldots \ldots$ D-1

APPENDIX E: ESTIMATED COSTS ASSOCIATED WITH THE DECOMMISSIONING OF THE CFBR AND PRU ......... E-1 


\section{LIST OF FIGURES}

Figure

Page

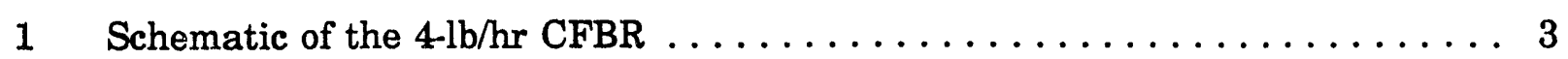

$24-\mathrm{lb} / \mathrm{hr}$ CFBR coal feed system $\ldots \ldots \ldots \ldots \ldots \ldots \ldots \ldots \ldots \ldots$

3 Reactor system of the $4-1 \mathrm{~b} / \mathrm{hr}$ CFBR $\ldots \ldots \ldots \ldots \ldots \ldots \ldots \ldots \ldots \ldots \ldots \ldots$

4 Flow sheet of the $100-1 \mathrm{~b} / \mathrm{hr}$ PRU $\ldots \ldots \ldots \ldots \ldots \ldots \ldots \ldots \ldots \ldots$

5 Three-dimensional flow sheet of the PRU operation $\ldots \ldots \ldots \ldots \ldots \ldots$

6 Mild gasification PRU carbonizer $\ldots \ldots \ldots \ldots \ldots \ldots \ldots \ldots \ldots \ldots \ldots \ldots$

7 Detail of upper $24 "$ diameter section $\ldots \ldots \ldots \ldots \ldots \ldots \ldots \ldots \ldots \ldots$

8 Detail of lower $24 "$ diameter section $\ldots \ldots \ldots \ldots \ldots \ldots \ldots \ldots \ldots \ldots$

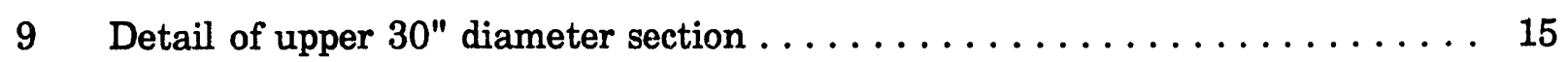

10 Detail of lower $30^{\prime \prime}$ diameter section $\ldots \ldots \ldots \ldots \ldots \ldots \ldots \ldots \ldots \ldots$

11 Carbonizer coal feed system $\ldots \ldots \ldots \ldots \ldots \ldots \ldots \ldots \ldots \ldots \ldots \ldots$

12 Primary carbonizer cyclone $\ldots \ldots \ldots \ldots \ldots \ldots \ldots \ldots \ldots \ldots \ldots \ldots$

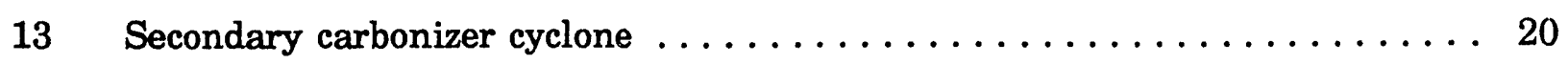

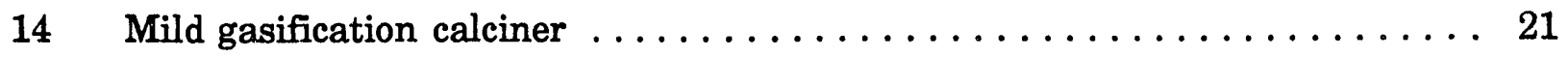

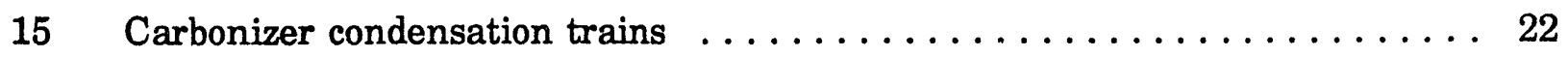

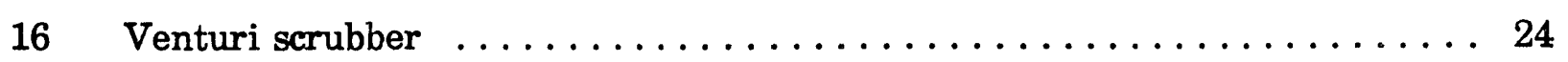

17 Venturi scrubber $\left(11 / 2^{\prime \prime}\right)$ interchangeable throat $\ldots \ldots \ldots \ldots \ldots \ldots 25$

18 Section above interchangeable throat $\ldots \ldots \ldots \ldots \ldots \ldots \ldots \ldots \ldots \ldots$

19 Section below interchangeable throat $\ldots \ldots \ldots \ldots \ldots \ldots \ldots \ldots \ldots 27$

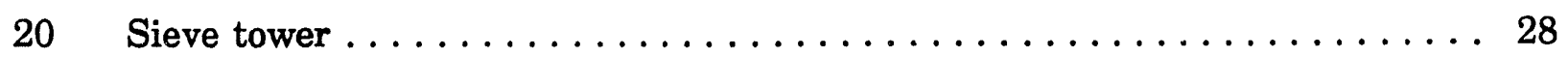

21 Venturi scrubber $4 "$ cyclone $\ldots \ldots \ldots \ldots \ldots \ldots \ldots \ldots \ldots \ldots \ldots \ldots$

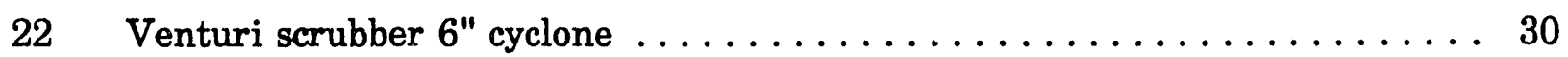

23 Calciner condensation train $\ldots \ldots \ldots \ldots \ldots \ldots \ldots \ldots \ldots \ldots \ldots \ldots \ldots \ldots \ldots \ldots$

24 Wastewater cleanup and phenol recovery system $\ldots \ldots \ldots \ldots \ldots \ldots . \ldots 32$ 


\section{LIST OF TABLES}

Table

$1 \quad$ PRU Electrical Requirements $\ldots \ldots \ldots \ldots \ldots \ldots \ldots \ldots \ldots \ldots \ldots \ldots \ldots$

2 Wyodak and Indiana Feed Coal and Char Analyses $\ldots \ldots \ldots \ldots \ldots \ldots$

3 Characterization of the Composite Condensate from Staged

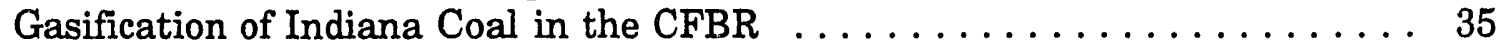

4 Characterization of Wyodak Coal Condensate Composite from CFBR

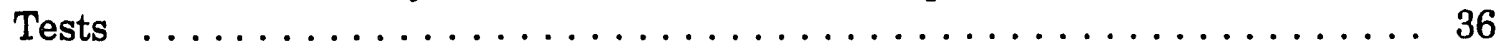

$5 \quad$ Analysis of Condensables from PRU Tests $\ldots \ldots \ldots \ldots \ldots \ldots \ldots$

6 Decant Oil, Fuel Oil, and Coal Tar Composite Characterization . . . . . . . . 38

7 Gas Composition from PRU Tests with Wyodak and Indiana No. $3 \ldots \ldots 8$

8 Mild Gasification Product Yields $\ldots \ldots \ldots \ldots \ldots \ldots \ldots \ldots$

9 Yield of Products from CFBR and PRU Tests . . . . . . . . . . . . . 42

10 Material Remaining for Disposal from CFBR and PRU Tests . . . . . . . . 42

11 Average Constituent Removals From the Biochemical Treatment of Indiana No. 3 Mild Gasification Process Condensate . . . . . . . . . . . 43 


\section{DEVELOPMENT OF AN ADVANCED, CONTINUOUS MILD GASIFICATION PROCESS FOR THE PRODUCTION OF CO-PRODUCTS}

\subsection{INTRODUCTION}

Coal is the largest indigenous energy resource in the United States. With the increasing consumption of petroleum products and electricity in this country, it is becoming increasingly important to develop processes that will allow the wider use of coal, including its use as a substitute for petroleum in energy and chemical markets. One approach is to develop a process that would be similar to a petroleum refinery in which several products are produced that meet the needs of different end users. Thus, within the process boundaries a high-value product could be maximized at the expense of a lowervalue product. The capability to alter product distributions, either by changing feedstocks or process conditions, would permit timely response to the ever-changing market. AMAX Coal Company described the coal refinery concept at the Twelfth International Conference on Slurry Technology (1).

In the mild gasification concept, for which research is sponsored by the Morgantown Energy Technology Center (METC) of the Department of Energy (DOE), rapid devolatilization of coal under mild conditions of temperature and pressure produces three products: a reactive char, a valuable hydrocarbon condensate, and a low-Btu gas. The process under development at the University of North Dakota Energy and Environmental Research Center (EERC) would produce activated carbon, a metallurgical coke substitute, diesel fuel additives, chemical feedstocks, and a low-Btu gas that would be used to cogenerate process heat and electrical power. 


\subsection{DESCRIPTION OF THE CONTINUOUS FLUIDIZED-BED REACTOR (CFBR), PROCESS RESEARCH UNIT (PRU), AND CO-PRODUCTS}

\subsection{Mild Gasification CFBR Description}

\subsubsection{Process Description}

A schematic of the 4-lb/hr CFBR is shown in Figure 1 . Its main components are the coal feed system, gas and/or steam superheater, fluidized-bed reactor, and gas and liquid separation.

Coal is fed continuously into the reactor by a one-sided ball feeder and an auger. The fluidization gas, typically nitrogen or argon, enters the bottom of the reactor after passing through the preheater and superheater. The reactor is externally heated using ceramic fiber heaters and typically operates at temperatures ranging from $932^{\circ} \mathrm{F}-1652^{\circ} \mathrm{F}$ $\left(500^{\circ} \mathrm{C}-900^{\circ} \mathrm{C}\right)$ and pressures below 75 psig. Gas, condensable liquids, and char are produced continuously in the fluidized-bed reactor. The coarse char is collected in the char collection pot and fines are removed from the gas stream in a cyclone. Condensable liquids are removed from the gas stream in a water-cooled condenser followed by two glycol-cooled condensers. The clean gas is finally metered by a gas meter, which is not shown in Figure 1.

\subsubsection{Coal Feed System}

The coal feed system is shown in relation to the bottom of the CFBR reactor in Figure 2. A "star" feeder, which is not shown, was placed directly above the 2-inch flange shown in the figure. The star feeder drops a specific volume of coal at selected intervals into the auger system. A small amount of purge gas is also fed into the auger system. The purge gas and high-speed auger swiftly move the coal into the reactor before devolatilization can occur, preventing agglomeration of the coal which could plug the feed system.

Plugging is often a problem in small coal feed systems. Because a small volume of material moves through a very narrow opening, coal particles stick together due to the high moisture content, and backflashing of hot gases from the reactor causes swelling. Plugging had been experienced on the $30-\mathrm{lb} / \mathrm{hr}$ pressurized fluidized-bed gasifier (PFBG) used on the Hydrogen Production from Coal project. The problem was resolved on the PFBG by slightly pressurizing the coal hopper and purging the auger; consequently, those features were added to the design of the $4-\mathrm{lb} / \mathrm{hr}$ CFBR.

The coal feed system has been calibrated for mass flow rates for several feed coals. Since the densities of the coals are slightly different, the star feeder revolution rate will vary with coal rank and crush size in order to maintain a constant mass flow rate. Typical mass flow rates for the feed system can range between $0.5 \mathrm{lb} / \mathrm{hr}$ and $8.0 \mathrm{lb} / \mathrm{hr}$. 


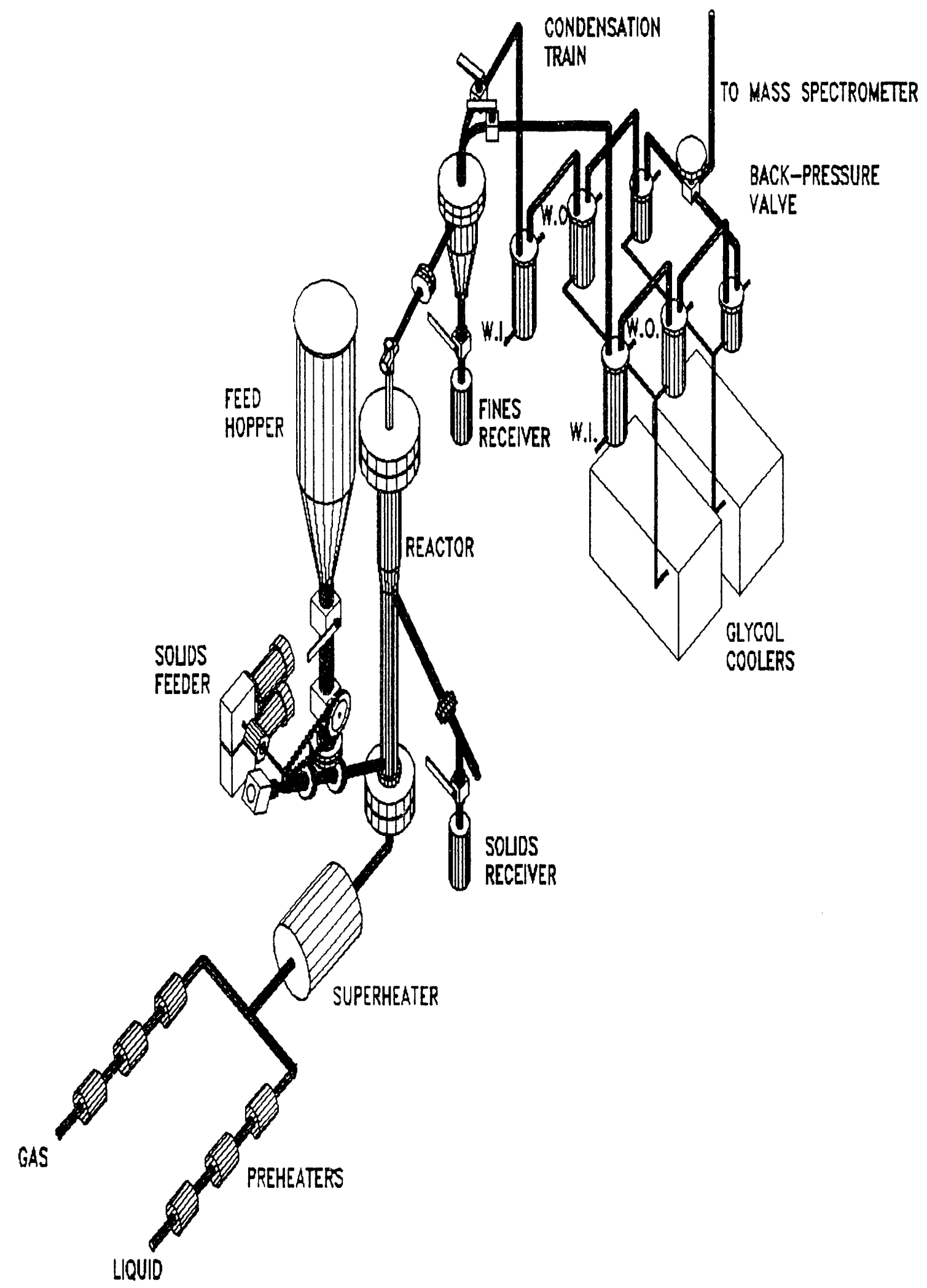

Figure 1. Schematic of the 4-lb/hr CFBR. 


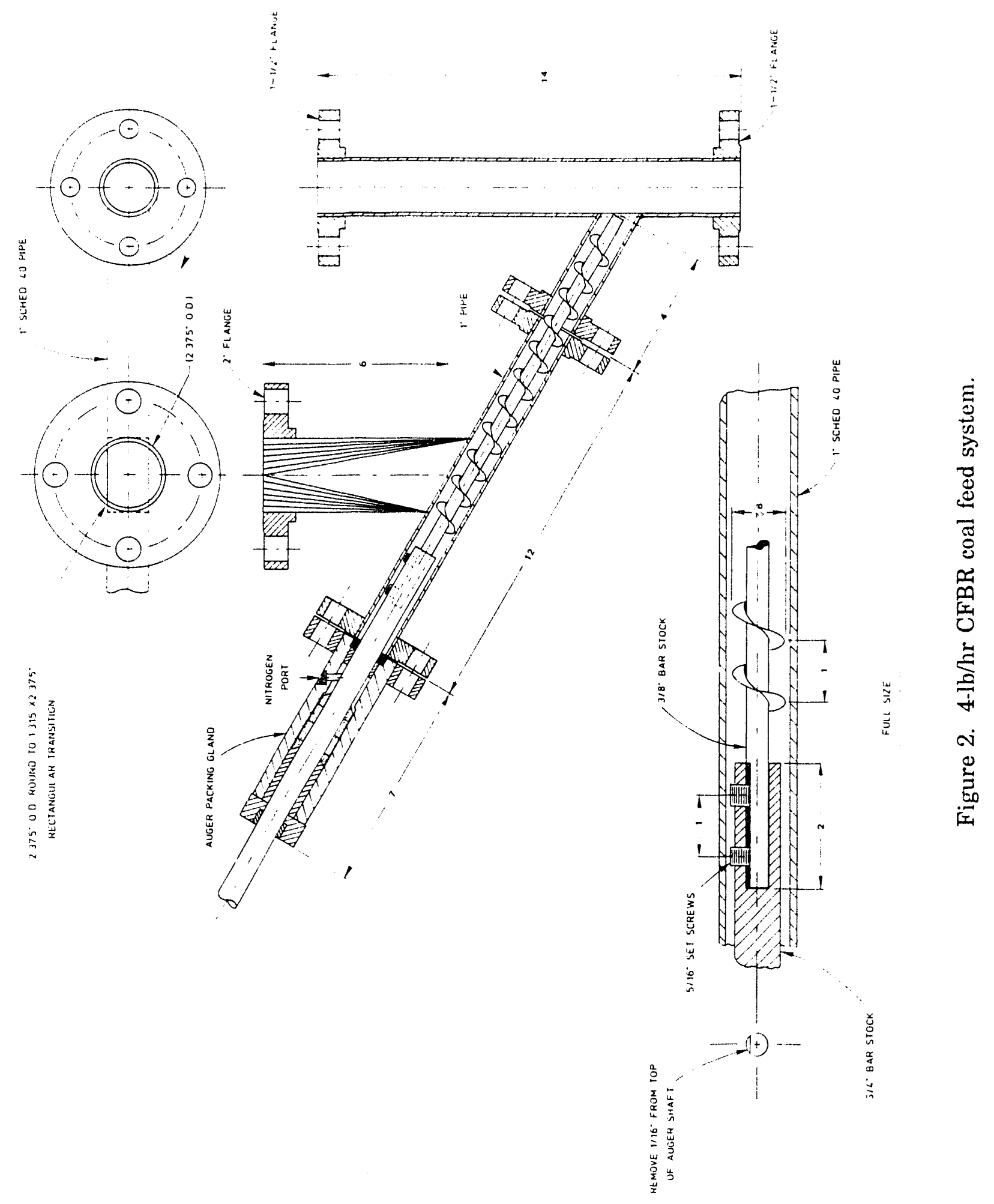




\subsubsection{Mild Gasification Reactor}

The reactor was constructed from two sections of Schedule $80,316 \mathrm{H}$ stainless steel (SS) pipe connected by a $316 \mathrm{H}$ SS weld reducer as shown in Figure 3. The bottom section is a 3-inch-nominal-diameter pipe, 33 inches long, which is connected to the coal feed system, and the top section is a 4-inch-nominal-diameter pipe, 18.75 inches long. The top and bottom flanges $(1500 \mathrm{lb})$ are $316 \mathrm{H}$ stainless steel, with Flexicarb SS gaskets rated at $1650^{\circ} \mathrm{F}\left(900^{\circ} \mathrm{C}\right)$ and 200 psia. The unit was designed so that the top of the fluid bed is 33 inches above the coal injection point. The char off-take leg at the top of the bed is the primary means of solids removal from the reactor. A ball valve facilitates the collection of char product when the system is in operation.

The reactor is heated using two ceramic fiber heaters which are capable of reaching $1800^{\circ} \mathrm{F}\left(980^{\circ} \mathrm{C}\right)$. The bottom heater is rated at 2500 watts, and the top heater is rated at 1775 watts. The heaters maintain the reactor temperature and eliminate hot spots. The use of external heaters allows for evaluation of different internal and external heating methods for process development and scaleup.

\subsubsection{Preheat System}

A variety of gases and gas/liquid mixes can be used for fluidization. The gases and liquids commonly used in the system include: nitrogen, air, oxygen, carbon monoxide, hydrogen, carbon dioxide, steam, and ethanol.

Gas enters the preheater cart and passes through a series of three tube heaters (Figure 1), which are capable of heating the gas to $842^{\circ} \mathrm{F}\left(450^{\circ} \mathrm{C}\right)$. Liquid is pumped into the system and also passes through a series of three tube heaters, which vaporize the liquid. Vaporized liquid can make up $0 \%$ to $100 \%$ of the fluidization gas.

After the preheaters, the gases and vaporized liquids are mixed tugether prior to entering the superheater. The superheater consists of a 20 -foot-long section of $3 / 8$ ". outside-diameter (OD) 316 SS tubing, coiled to approximately $3 \frac{1}{2}$ " OD and 10" long. This coil is inside a $5^{\prime \prime}$-inside-diameter (ID) ceramic fiber heater, capable of reaching a temperature of $2000^{\circ} \mathrm{F}\left(1093^{\circ} \mathrm{C}\right)$. From the superheater, the fluidization gas enters the bottom of the reactor through a transfer tube heated by cable heaters.

\subsubsection{Gas Quench and Liquid Separation}

A cyclone constructed of Schedule 80,3 -inch-diameter $316 \mathrm{H}$ stainless steel is used to remove fines from the gas stream. The fines are collected in a catch pot. A ball valve allows changing of the catch pot for fines removal when the system is in operation. The cyclone is heated with a ceramic fiber heater, capable of reaching $1650^{\circ} \mathrm{F}\left(900^{\circ} \mathrm{C}\right)$ to minimize condensation and plugging by fines. 

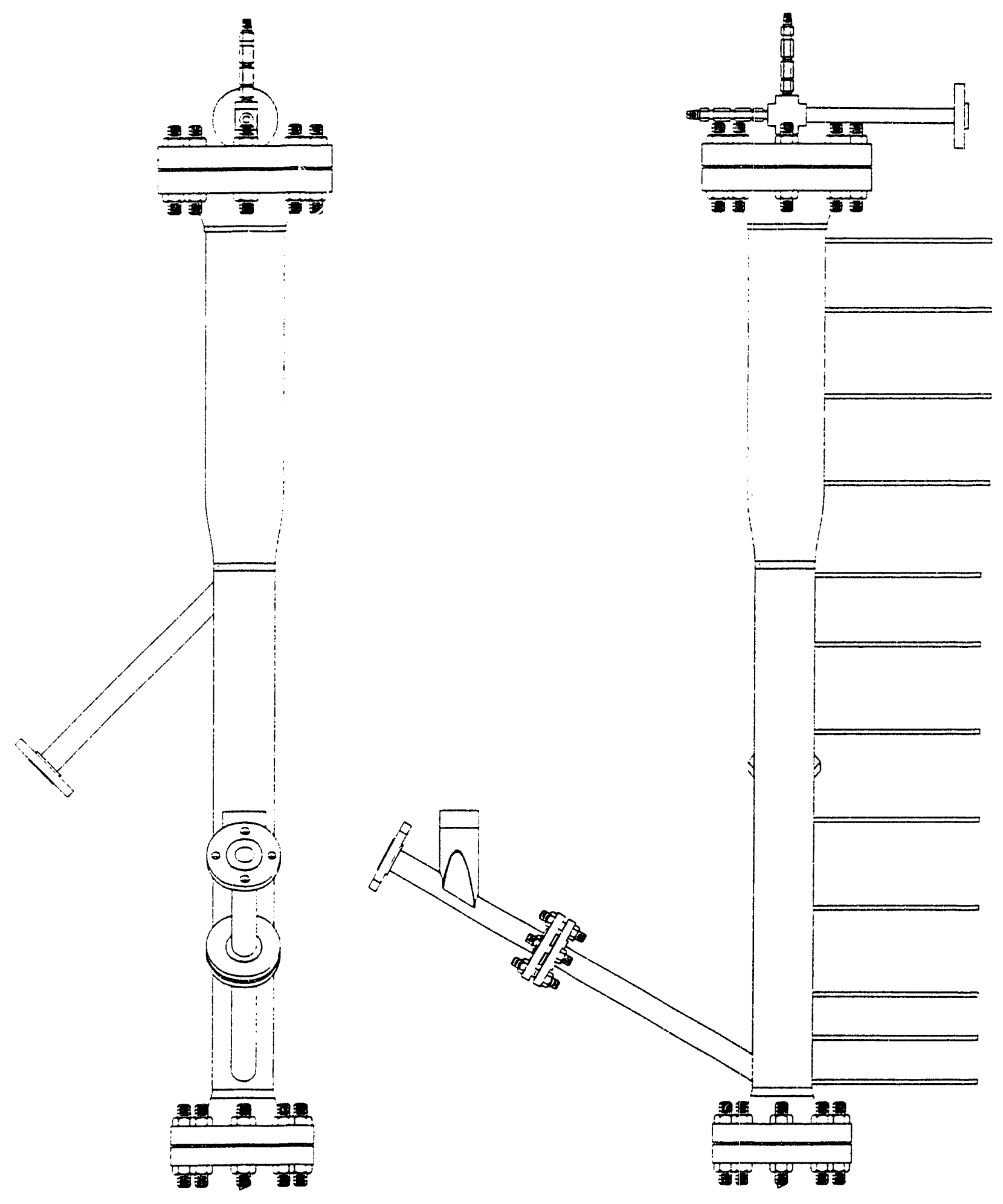

Figure 3. Reactor system of the 4-lb/hr CFBR. 
After the cyclone, two parallel sets of three 4-inch-diameter vessels are used to remove the condensable material from the gas stream. Two separate trains were installed: one for mass balance sampling, and the other for heatup, un-steady-state conditions, and cooldown. The first condenser pot is water-cooled and typically cools the gas stream from $570^{\circ} \mathrm{F}\left(300^{\circ} \mathrm{C}\right)$ to $200^{\circ}\left(95^{\circ} \mathrm{C}\right)$. The last two condenser pots in each set are glycol-cooled. The exit gas temperature is typically $50^{\circ} \mathrm{F}\left(10^{\circ} \mathrm{C}\right)$. A glass wool filter captures aerosols that pass through the condenser system.

\subsection{Mild Gasification PRU Description}

\subsubsection{Process Description}

Design of the $100-1 \mathrm{~b} / \mathrm{hr}$ mild gasification process research unit (PRU), shown in Figure 4, was initiated in November 1988. For design purposes, the PRU was divided into eight areas as follows:

$\begin{array}{ll}\text { Area 100 } & \text { Coal Preparation } \\ \text { Area 200 } & \text { Utilities } \\ \text { Area 300 } & \text { Carbonization } \\ \text { Area 400 } & \text { Calcination } \\ \text { Area 500 } & \text { Gas Quench/Liquid Separation } \\ \text { Area 600 } & \text { Wastewater Treatment/Phenol Recovery } \\ \text { Area 700 } & \text { Char Upgrading } \\ \text { Area 800 } & \text { Liquid Upgrading }\end{array}$

Appendix A lists the major pieces of PRU equipment.

Figure 5 shows a three-dimensional flow diagram of the PRU operation. The objectives of the PRU within the development of the mild gasification concept are to: 1 ) provide proof of concept for an integrated design operating using specific design coals, and 2) produce char and liquid products for upgrade testing and market evaluation.

The PRU was designed to process $100 \mathrm{lb} / \mathrm{hr}$ of feed coal on a dry basis. The process is capable of drying, carbonizing, and calcining both caking and noncaking coals in fluidized-bed reactors, with provisions for separating char, liquid, and gaseous products. The PRU was designed for integrated operation using both the carbonizer and the calciner; however, it can also be operated using only the carbonizer.

The carbonizer and calciner are heated principally using flue gas from the stoichiometric combustion of natural gas. In a commercial design, heat could be supplied from the combustion of process-derived gas and waste coal from coal cleaning in a fluidbed combustor. Air-blown external combustion is used to heat the gasifiers to avoid the high cost of an oxygen plant in the commercial design. Provisions were made for steam injection into the carbonizer to improve sulfur removal and increase liquid quality. Hightemperature steam can also be used in the calciner for the production of activated carbon, or to increase the $\mathrm{H}_{2}$ and $\mathrm{CO}$ content of the gas sent from the calciner to the carbonizer during integrated operation. 


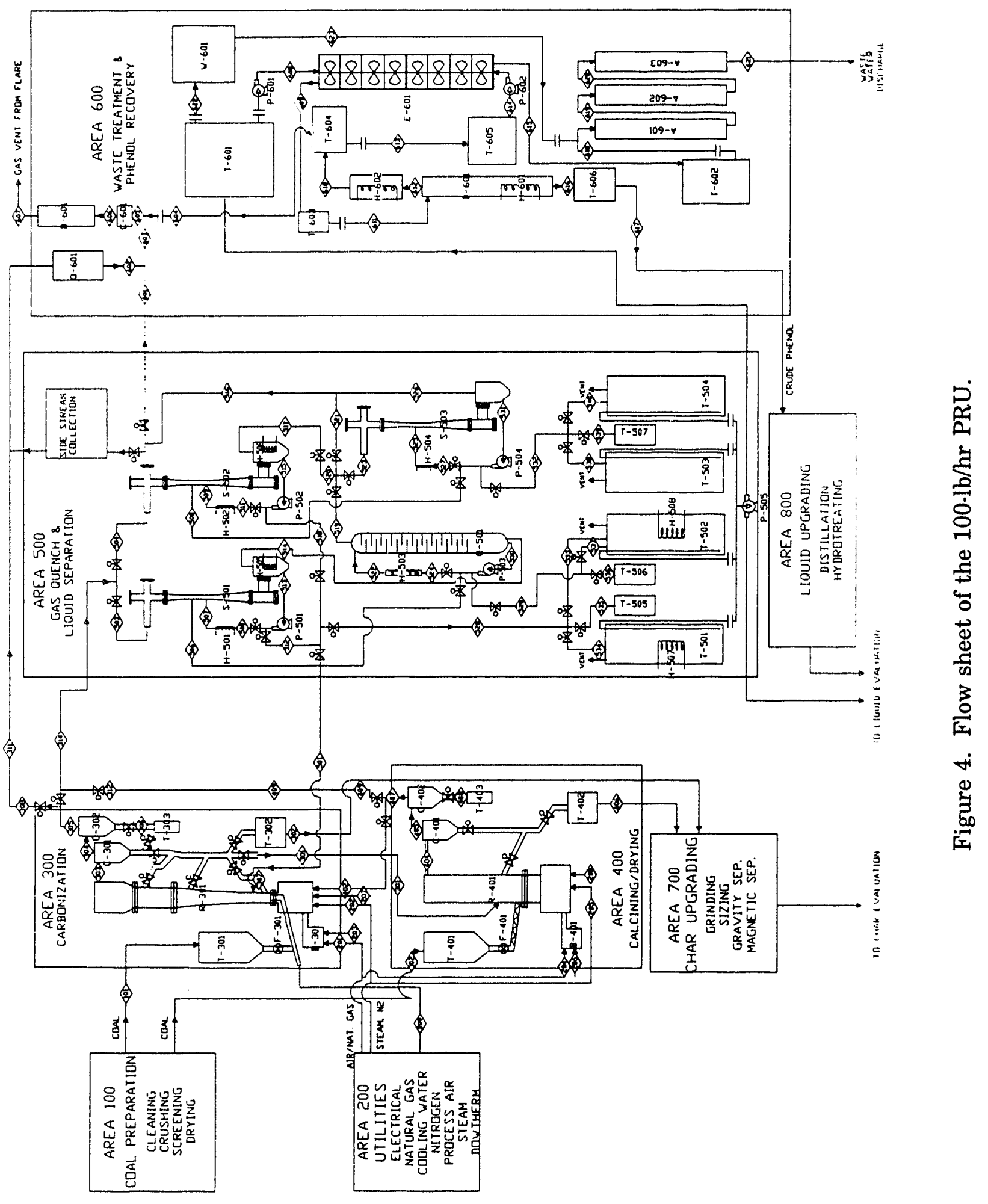




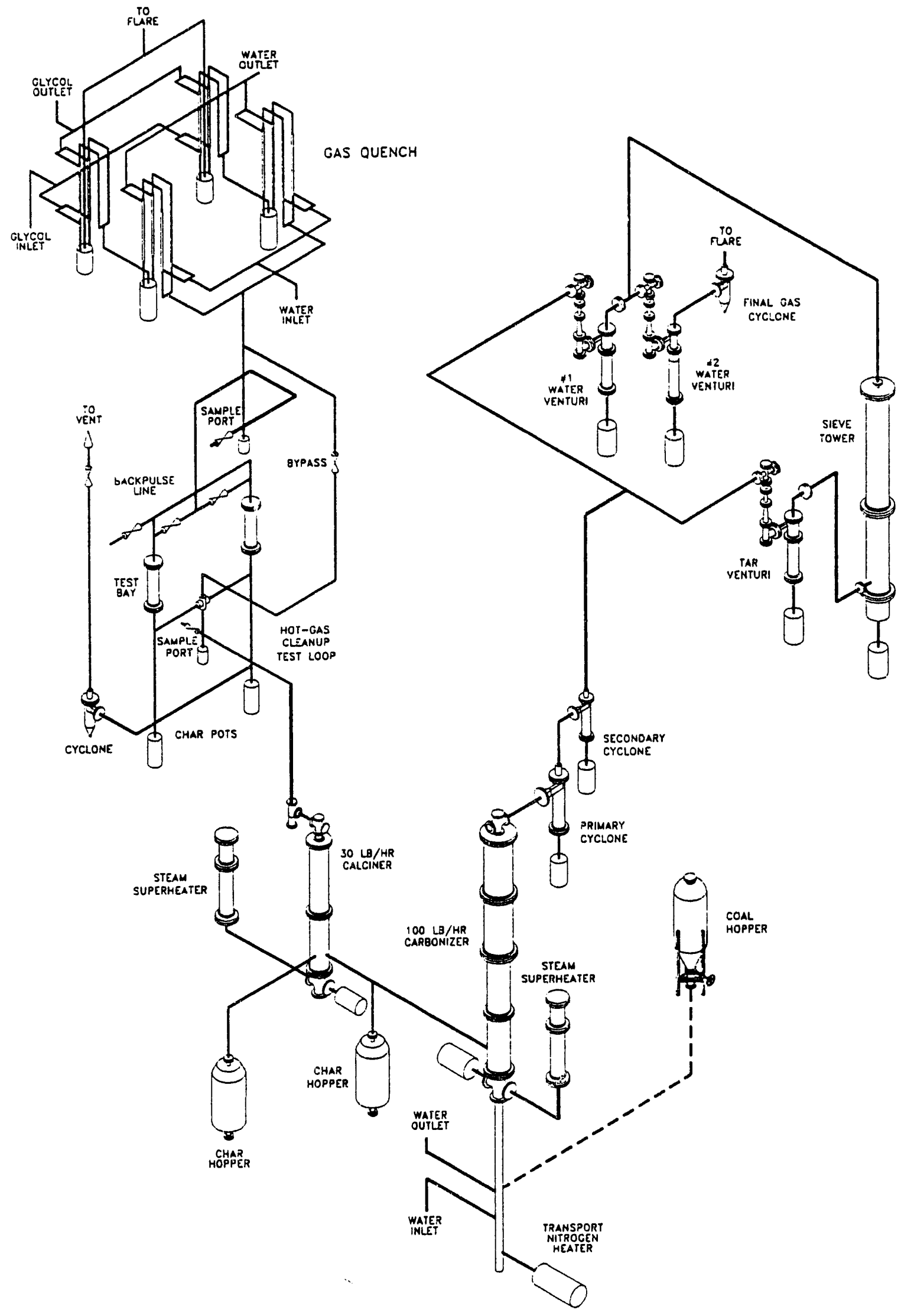

Figure 5. Three-dimensional flow sheet of the PRU operation. 


\subsubsection{Coal Preparation}

Area 100 is coal preparation. The two coals tested in the $100-\mathrm{lb} / \mathrm{hr}$ mild gasification PRU were Wyodak from the Eagle Butte mine near Gillete, Wyoming, and Indiana No. 3 from the Chinook mine near Brazil, Indiana. Twenty-five tons of washed coal product from each mine were delivered to the EERC, sized to $2 "$ " 0 , and stored in nitrogen-purged bunkers. Prior to processing in the PRU, the coal was crushed to $1 / 4 "$ " $\times 0$.

Drying the feed coal to reduce the moisture content was one of the variables evaluated in PRU testing. A steam dryer was available to dry the coal before entering the carbonizer. The objective of drying the feed coal was to reduce or eliminate the net production of wastewater during the low-steam tests. If lower moisture contents were desired, the coal was further dried at low temperature $\left(<570^{\circ} \mathrm{F} / 300^{\circ} \mathrm{C}\right)$ in the carbonizer.

\subsubsection{Utility Requirements}

The utilities area, Area 200, consists of the following:

1) Electrical Service

2) Natural Gas

3) Cooling Water

4) Nitrogen

5) Process Air

6) Steam Boiler \& Superheater

The boiler, which supplies steam to the PRU, has the capacity to deliver 370 pounds per hour of $250^{\circ} \mathrm{F}\left(121^{\circ} \mathrm{C}\right)$ saturated steam. The electric superheater can heat 200 pounds of steam per hour from $250^{\circ} \mathrm{F}\left(121^{\circ} \mathrm{C}\right)$ to $1400^{\circ} \mathrm{F}\left(760^{\circ} \mathrm{C}\right)$.

A list of the electrical requirements is shown in Table 1. The total requirement is approximately 405 amps, with the majority of the load consumed by heat tracing of the reactor and product gas lines.

\subsubsection{Carbonizer}

Area 300 contains the carbonizing reactor, two cyclones, a coal feed system, and a natural gas burner. The carbonizer (shown in Figure 6) is operated as a spouting bed reactor at temperatures from $900^{\circ} \mathrm{F}\left(480^{\circ} \mathrm{C}\right)$ to $1100^{\circ} \mathrm{F}\left(600^{\circ} \mathrm{C}\right)$, and at steam partial pressures from $10 \%$ to $60 \%$. This design was chosen based on favorable results with caking coals in the COALCON and KRW gasifier systems. The operative principle allowing the use of caking coal in this reactor is the dilution of the entering coal by an internal recycle of char back to the bottom of the tapered bed, where high velocity and low bed density also reduce agglomeration. A similar regime existed in the $400-\mathrm{lb} / \mathrm{hr}$ fast fluidized-bed Perry carbonizer previously used with caking coals at the Grand Forks Energy Technology Center (GFETC), Grand Forks, North Dakota (1). The body of the carbonizer consists of four 5-foot tall sections. The modular design of the carbonizer allows removal of different sections to obtain a variety of gas and char residence times. 
TABLE 1

PRU Electrical Requirements

\begin{tabular}{|c|c|c|c|}
\hline Heaters & Voltage & Amps & Total Amps \\
\hline $\mathrm{N}_{2}$ Transport & $120 \mathrm{~V} 10$ & $15.67 \mathrm{~A}$ & $15.67 \mathrm{~A}$ \\
\hline Superheater & $480 \mathrm{~V} 30$ & $43.40 \mathrm{~A}$ & $43.40 \mathrm{~A}$ \\
\hline Keactor Heaters & $240 \mathrm{~V} 30$ & $166.30 \mathrm{~A}$ & $166.30 \mathrm{~A}$ \\
\hline Drum Heaters & $230 \mathrm{~V} 30$ & $11.10 \mathrm{~A}$ & $11.10 \mathrm{~A}$ \\
\hline Downleg Pipes & $240 \mathrm{~V} 30$ & $14.40 \mathrm{~A}$ & $14.40 \mathrm{~A}$ \\
\hline Primary Cyclone & $240 \mathrm{~V} 10$ & $20.50 \mathrm{~A}$ & $20.50 \mathrm{~A}$ \\
\hline Secondary Cyclone & $240 \mathrm{~V} 10$ & $8.75 \mathrm{~A}$ & $8.75 \mathrm{~A}$ \\
\hline Reactor Cross & 208V 10 & $21.70 \mathrm{~A}$ & $21.70 \mathrm{~A}$ \\
\hline $750^{\circ} \mathrm{F}$ Venturi/Cyclones & $208 V 30$ & $9.20 \mathrm{~A}$ & $36.80 \mathrm{~A}$ \\
\hline $350^{\circ} \mathrm{F}$ Venturi/Cyclones & $208 \mathrm{~V} 30$ & $4.60 \mathrm{~A}$ & $9.20 \mathrm{~A}$ \\
\hline $2 "$ Interconnect Piping & $208 V 30$ & $0.70 \mathrm{~A} / \mathrm{ft}$ & $24.50 \mathrm{~A}$ \\
\hline 3" Interconnect Piping & $208 \mathrm{~V} 30$ & $0.70 \mathrm{~A} / \mathrm{ft}$ & $3.50 \mathrm{~A}$ \\
\hline \multirow[t]{2}{*}{ Sieve Tower Heaters } & $208 V 30$ & $9.00 \mathrm{~A}$ & $29.00 \mathrm{~A}$ \\
\hline & Voltage & Horsepower & \\
\hline Coal Feed & $208 \mathrm{~V} 30$ & $0.75 \mathrm{HP}$ & \\
\hline Auger & $208 V 30$ & $0.75 \mathrm{HP}$ & \\
\hline Tar Recycle Pump & $208 \mathrm{~V} 30$ & $5.00 \mathrm{HP}$ & \\
\hline Tar Transfer Pump & $208 V 30$ & $1.50 \mathrm{HP}$ & \\
\hline 3 Centrifuge Pumps & $208 V 30$ & $1.00 \mathrm{HP}$ & \\
\hline
\end{tabular}

The lower two sections are constructed of 24" 304L stainless steel pipe. The pipe is lined with 5.25" of insulating refractory and two layers of hard, abrasion-resistant refractory, resulting in an 8" inside diameter, as shown in Figures 7 and 8. The two upper sections are constructed of $30^{\prime \prime} 304 \mathrm{~L}$ stainless steel pipe. The pipe is lined with $4.625^{\prime \prime}$ of insulating refractory and 2 " of hard refractory, resulting in a 16 " inside diameter, as shown in Figures 9 and 10. 


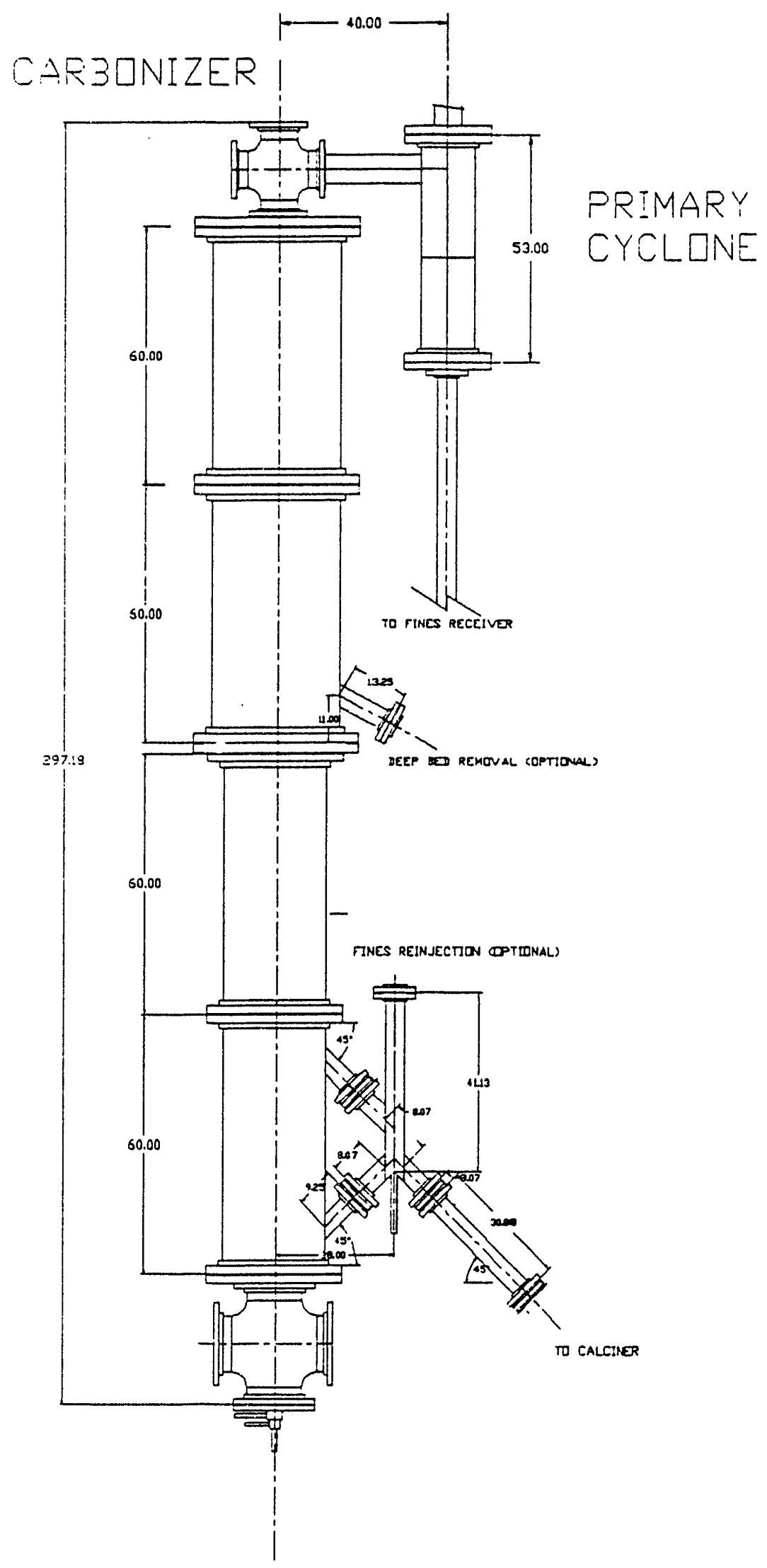

Figure 6. Mild gasification PRU carbonizer. 


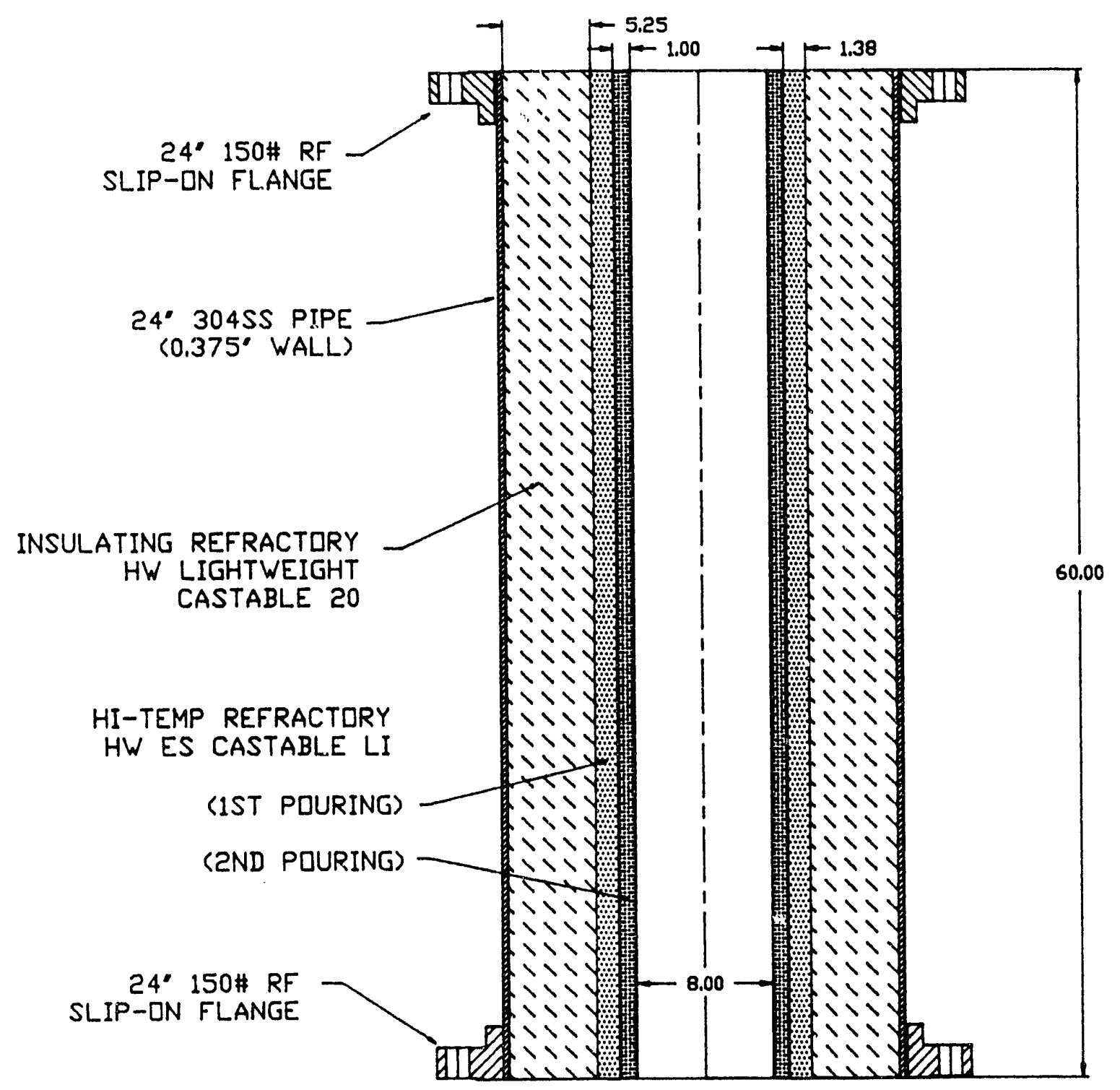

Figure 7. Detail of upper 24" diameter section. 


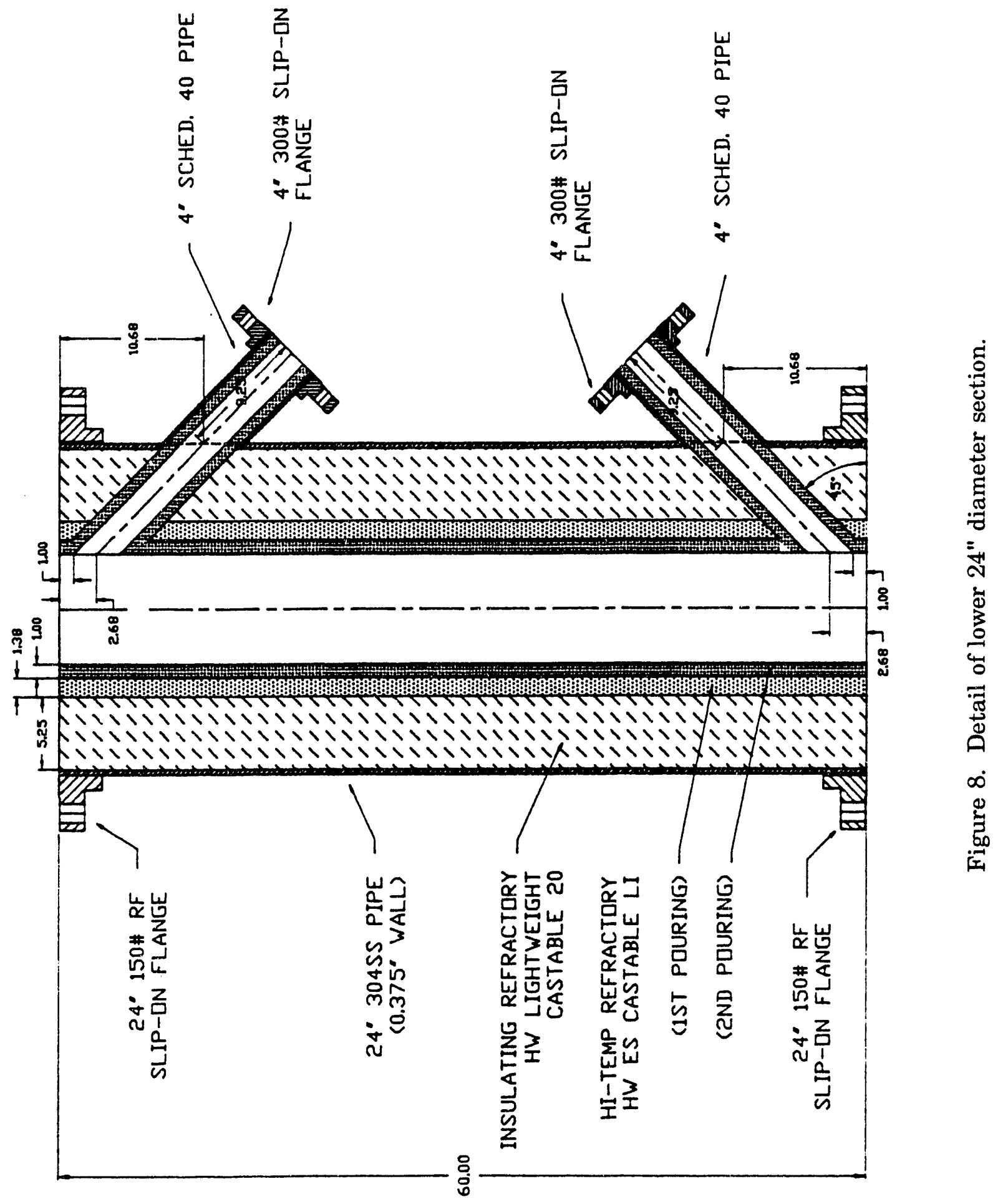




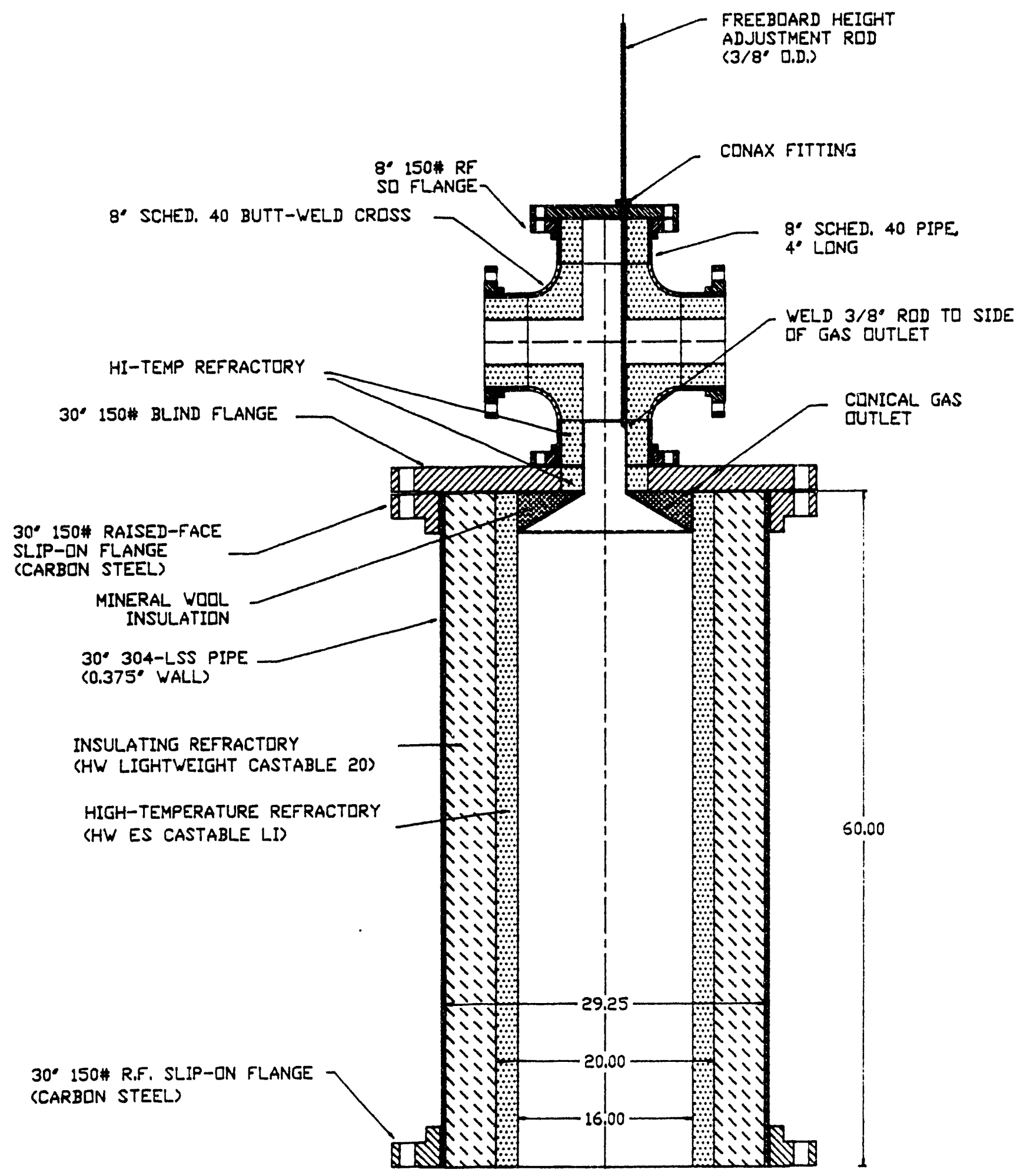

Figure 9. Detail of upper 30" diameter section. 


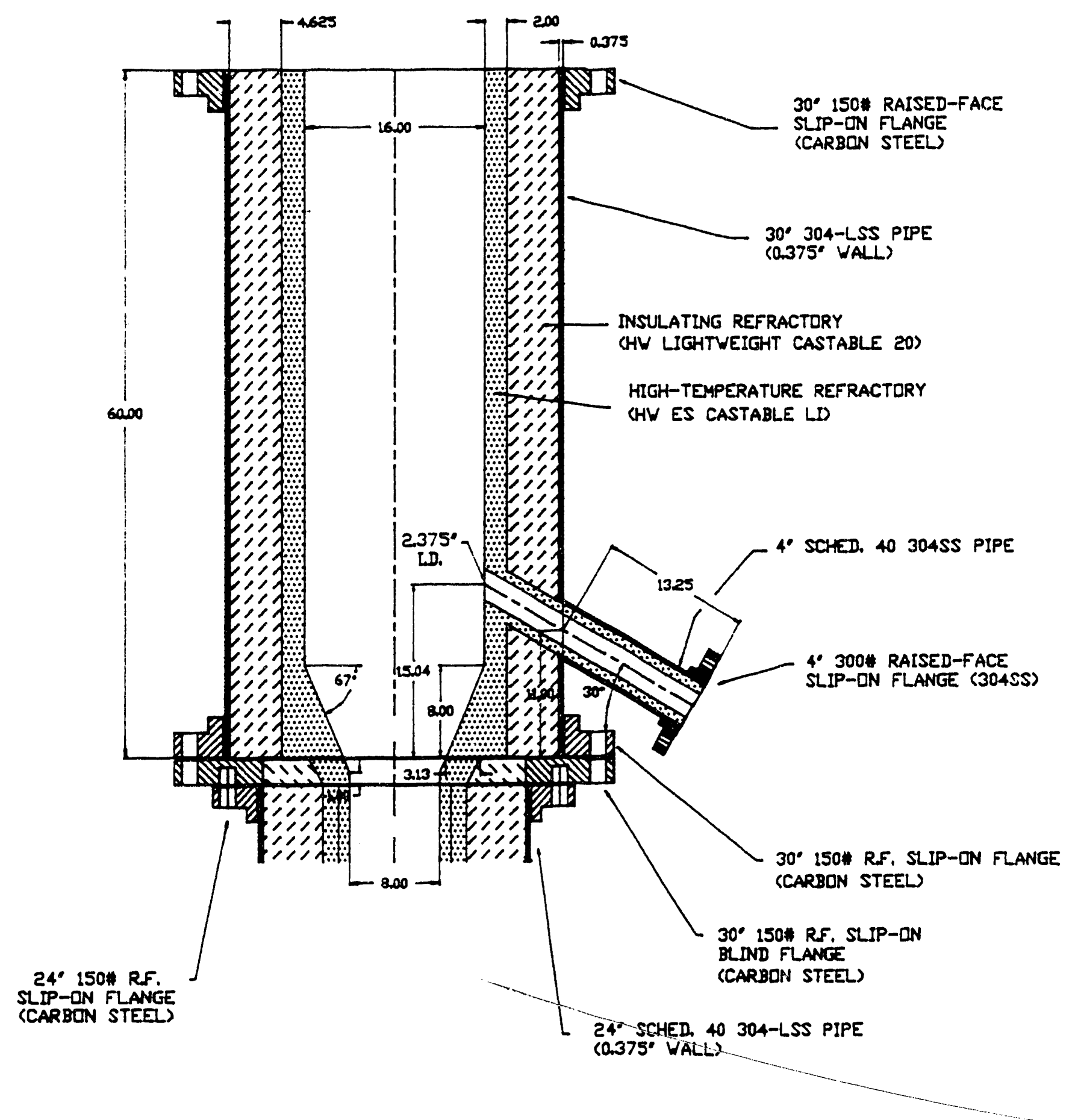

Figure 10. Detail of lower 30" diameter section. 
The smaller diameter of the lower sections of the reactor is intended to increase the velocity and turbulence of the bed and thus reduce agglomeration of the test coals. When the fast-moving gas jet enters the larger-diameter upper section, its velocity decreases. The char entrained in the gas jet falls back into the lower section and dilutes the fresh coal entering the bottom of the reactor, providing a longer residence time for the char.

The fluidization gases are heated by a stoichiometrically-operated natural gas burner. The desired operating temperature was maintained by adding air and/or steam or nitrogen to the burner gas in the carbonizer plenum. The coal is entrained and fed into the bottom of the reactor using preheated nitrogen $\left(572^{\circ} \mathrm{F} / 300^{\circ} \mathrm{C}\right)$ via a system of lock hoppers, augers, and pneumatic transports, as shown in Figure 11. The coal from the lock hopper is gravity-fed into a star feeder that supplies coal at the desired flow rate. The star feeder drops the coal into a 1"-diameter auger that forces tine coal into a high-velocity stream of preheated nitrogen, which carries the coal into the bed of the carbonizer. The char can be withdrawn from a variety of locations and sent to the calciner or removed from the system and cooled in a nitrogen-purged tote bin. The char fines entrained by the gases leaving the top of the carbonizer are separated from the gas stream by a pair of cyclones. The primary cyclone removes particles greater than $10.7-\mu \mathrm{m}$ in size with $50 \%$ efficiency. The secondary cyclone can remove particles down to $4.02-\mu \mathrm{m}$ in size with $50 \%$ efficiency.

The cyclones are constructed of 304 SS pipe. As shown in Figures 12 and 13, refractory was cast inside the pipes to form the cones at the bottoms of the cyclones. The fines are removed from the hot gas stream by the cyclones and collected in a lock hopper.

\subsubsection{Calcining/Drying System}

The calcining/drying system, Area 400, consists of the calcining reactor (see Figure 14), cyclones, and feed system. Material is fed into the reactor using an auger, or, in the case of integrated operation, through a leg connecting the carbonizer to the calciner. The bubbling fluidized-bed reactor has an inside diameter of 6 " and operates at temperatures up to $1650^{\circ} \mathrm{F}\left(900^{\circ} \mathrm{C}\right)$. The reactor is lined with $4^{\prime \prime}$ of insulating refractory and 2 " of hard refractory. A stoichiometrically regulated natural gas burner heats the fluidizing gas. The temperature in the reactor is controlled by adding nitrogen and/or steam in the plenum and by combustion of natural gas/air.

Char is withdrawn from the reactor through a char off-take leg and cooled in a tote bin purged with an inert blanket of nitrogen. The gas from the calciner is flared after passing through the condensation train. The calciner gas can also be diverted to the carbonizer for integrated operation. The calciner may also be used to produce activated carbon from the char produced in the carbonizer, with flue gas and steam at temperatures up to $1475^{\circ} \mathrm{F}\left(802^{\circ} \mathrm{C}\right)$ as the fluidizing gas.

\subsubsection{Gas Quench and Liquid Separation}

Area 500 contains the carbonizer and calciner condensation trains. The process includes two independent carbonizer condensation trains, as shown in Figure 15. In the first carbonizer condensation train, the gas stream from the cyclones passes through a venturi tar scrubber, then through a sieve tower, and finally through a water scrubber. 


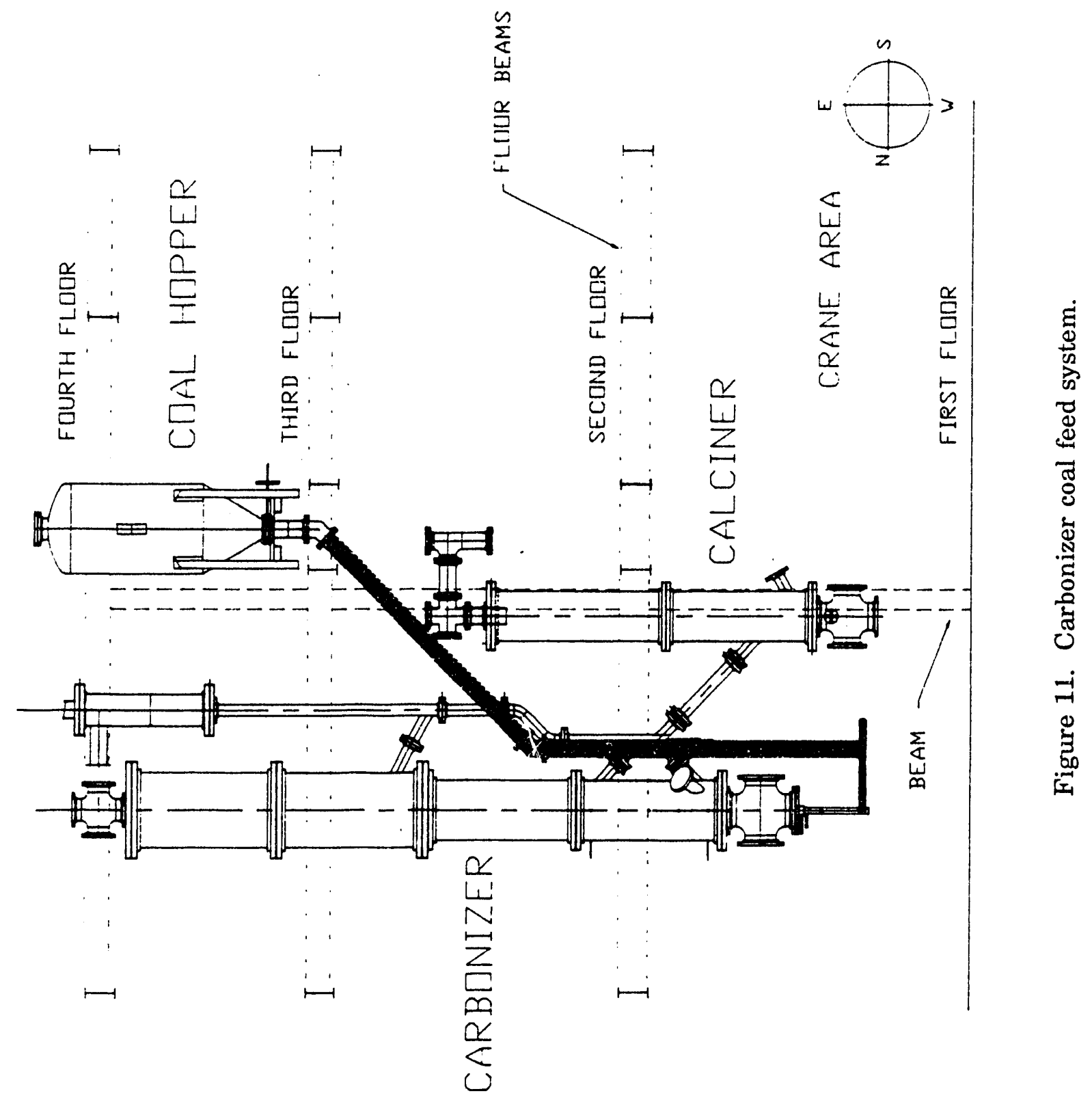




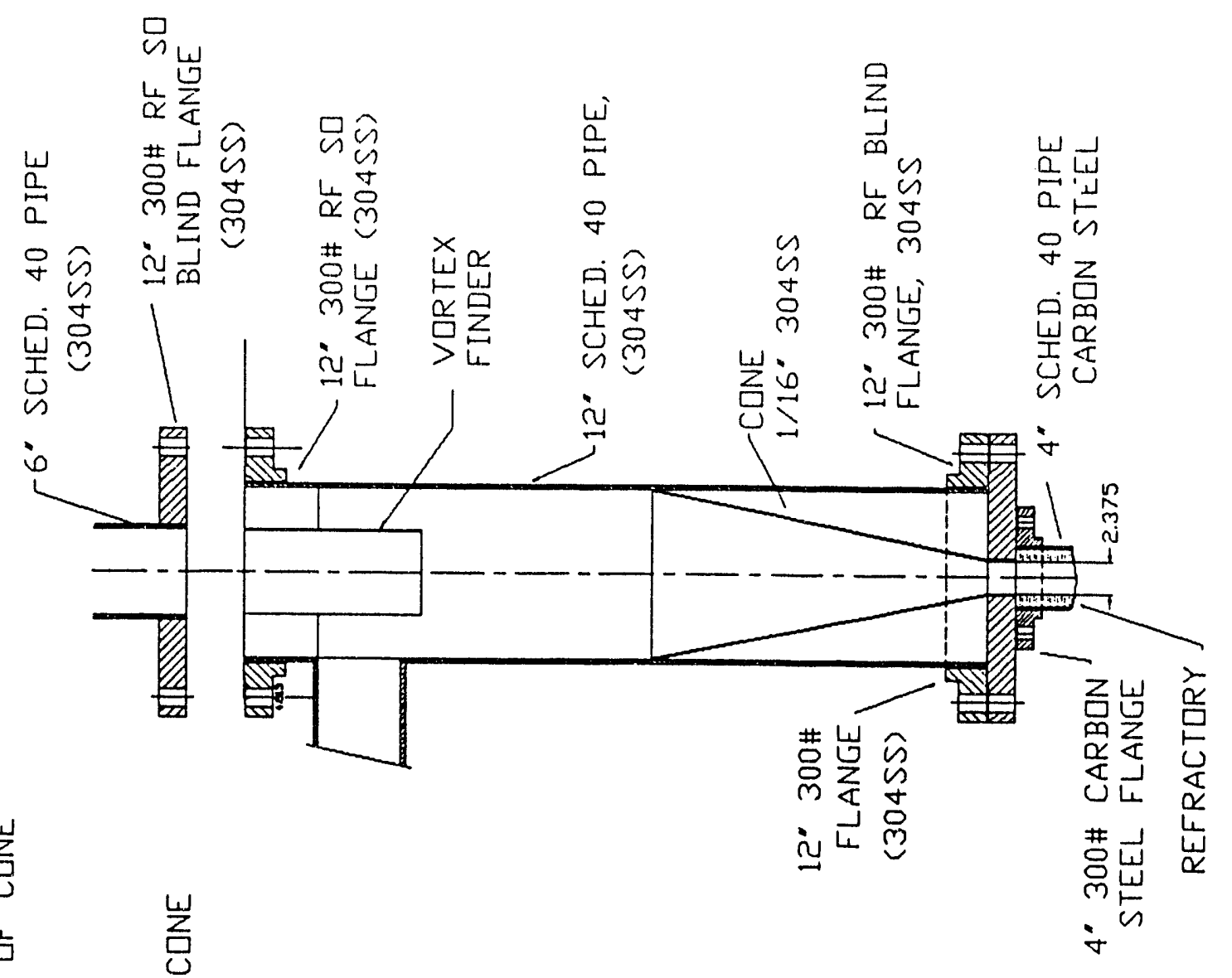

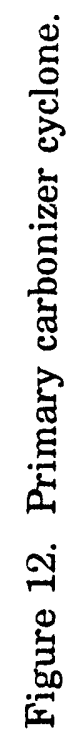


Figure 3. Reactor system of the $4-\mathrm{lb} / \mathrm{hr}$ CFBR.

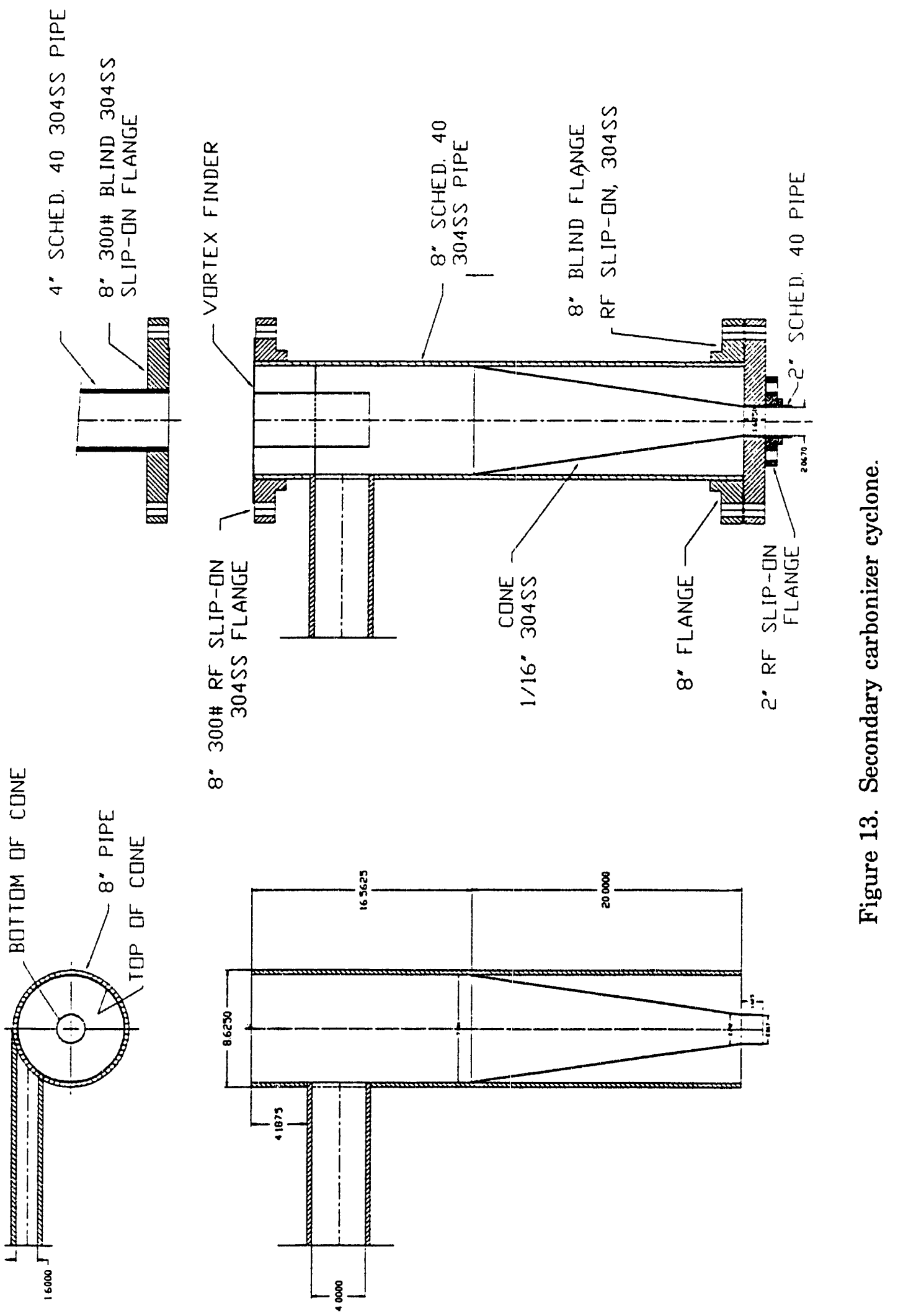




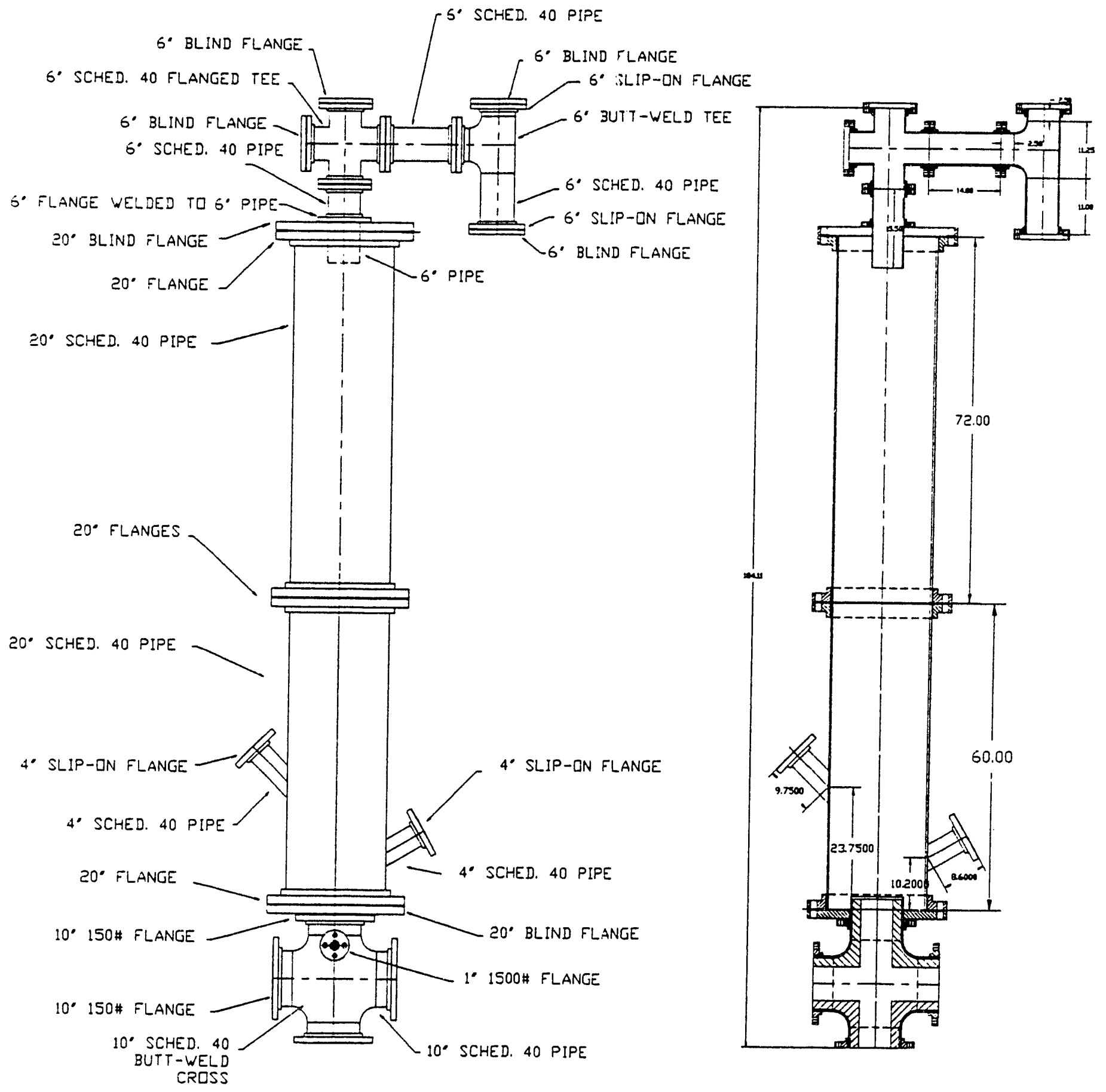

Figure 14. Mild gasification calciner. 


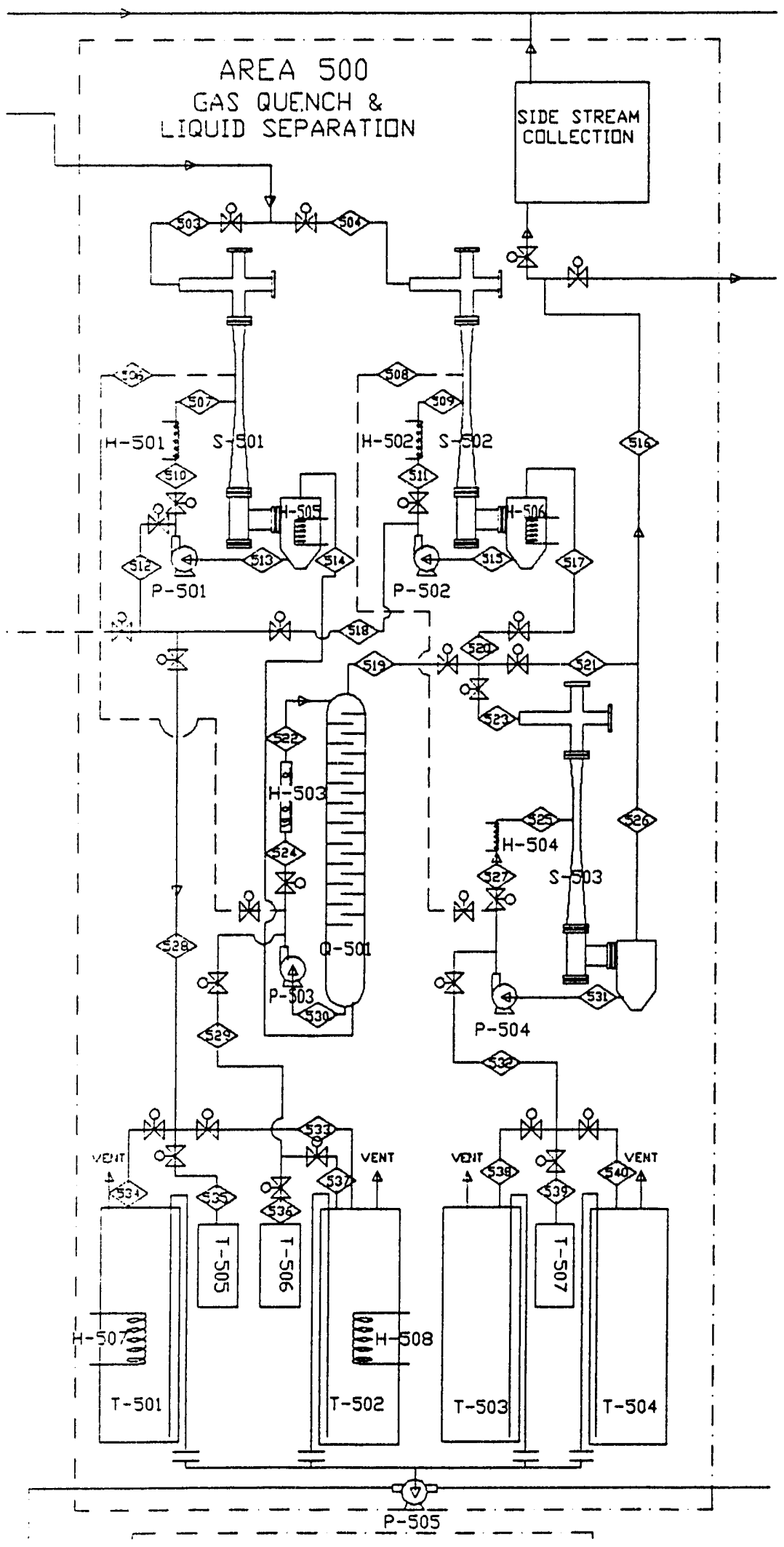

Figure 15. Carbonizer condensation trains. 
The first condensation train is used when steam is not used in the fluidization gas. Part of the liquid stream from a cyclone located after the venturi tar scrubber is cooled and reinjected into the venturi scrubber. The remainder is stored in 55-gallon barrels. Liquid is reinjected either through two spray nozzles perpendicular to the gas flow at the opening in the venturi throat, or through the top of the venturi (Figure 16). The venturis have interchangeable throats, with throat diameters of 1", 11/4", 11/2", and 13/4" available. The 11/2" diameter throat is shown in Figure 17. Figure 18 shows the section above the interchangeable throat, and Figure 19 shows the section below it. The temperature of the gas stream leaving the tar venturi ranges from $500^{\circ} \mathrm{F}-700^{\circ} \mathrm{F}\left(260^{\circ} \mathrm{C}-370^{\circ} \mathrm{C}\right)$. The gas stream from the top of the tar cyclone enters the bottom of the sieve tower (Figure 20), where it passes through a series of perforated plates. The plates in the sieve tower are connected for easy removal in the event of plugging. In the sieve tower, recycle oil from the bottom of the tower is cooled and used to quench the incoming gas. Heat exchangers are used to cool the recycle streams in both the tar venturi and the sieve tower. The tar and oil product is placed in 55-gallon barrels for storage and/or analysis. After the sieve tower, the gas enters a direct contact water scrubber (venturi cyclone). Then the gas, at the water dew point, is sent to the flare.

The second carbonizer condensation train consists of a series of two direct contact water scrubbers (venturi cyclones), shown in Figures 21 and 22, which is used when steam is a component of the fluidization gas. The gas stream is cooled to between $200^{\circ} \mathrm{F}\left(93^{\circ} \mathrm{C}\right)$ and $225^{\circ} \mathrm{F}\left(107^{\circ}\right)$ in the first water scrubber and to below $125^{\circ} \mathrm{F}\left(52^{\circ} \mathrm{C}\right)$ in the second scrubber. The gas from the second venturi is flared, and the liquid products are stored in 55-gallon barrels.

The calciner condensation train, shown in Figure 23, consists of a series of three paired shell and tube heat exchangers for product separation. The first set of heat exchangers is glycol-cooled, and the other two sets are water-cooled. A duplicate train of exchangers was installed so gas flow could be switched to the other side if plugging occurred. Cryogenic traps were placed after the shell and tube heat exchangers to condense lower-boiling point materials out of the gas stream. After passing through the calciner condensation train, the gas was flared.

Samples of product gas from both the carbonizer and the calciner were analyzed using a Pro Spec 2000 mass spectrometer which is capable of analyzing up to 50 streams, with 1 to 16 components per stream. A total gas analysis is completed in 10-20 seconds, and the components analyzed range from 2 to $400 \mathrm{amu}$ in molecular weight. In addition, analyses of the combustion gases from the carbonizer and calciner burners were used by the burner controllers to maintain the stoichiometric ratio of natural gas and air. The mass spectrometer was also used to analyze gas samples from two locations in the tower, to monitor carbon monoxide and other hazardous gases.

\subsubsection{Waste Treatment and Phenol Recovery}

The use of steam for part or all of the fluidiring gas produces wastewater which must be treated prior to discharge. Typically, wastewater treatment consists of biotreatment, with or without dilution with clean water. The EERC wastewater treatment and phenol recovery scheme is shown in Figure 24. The process is based on 


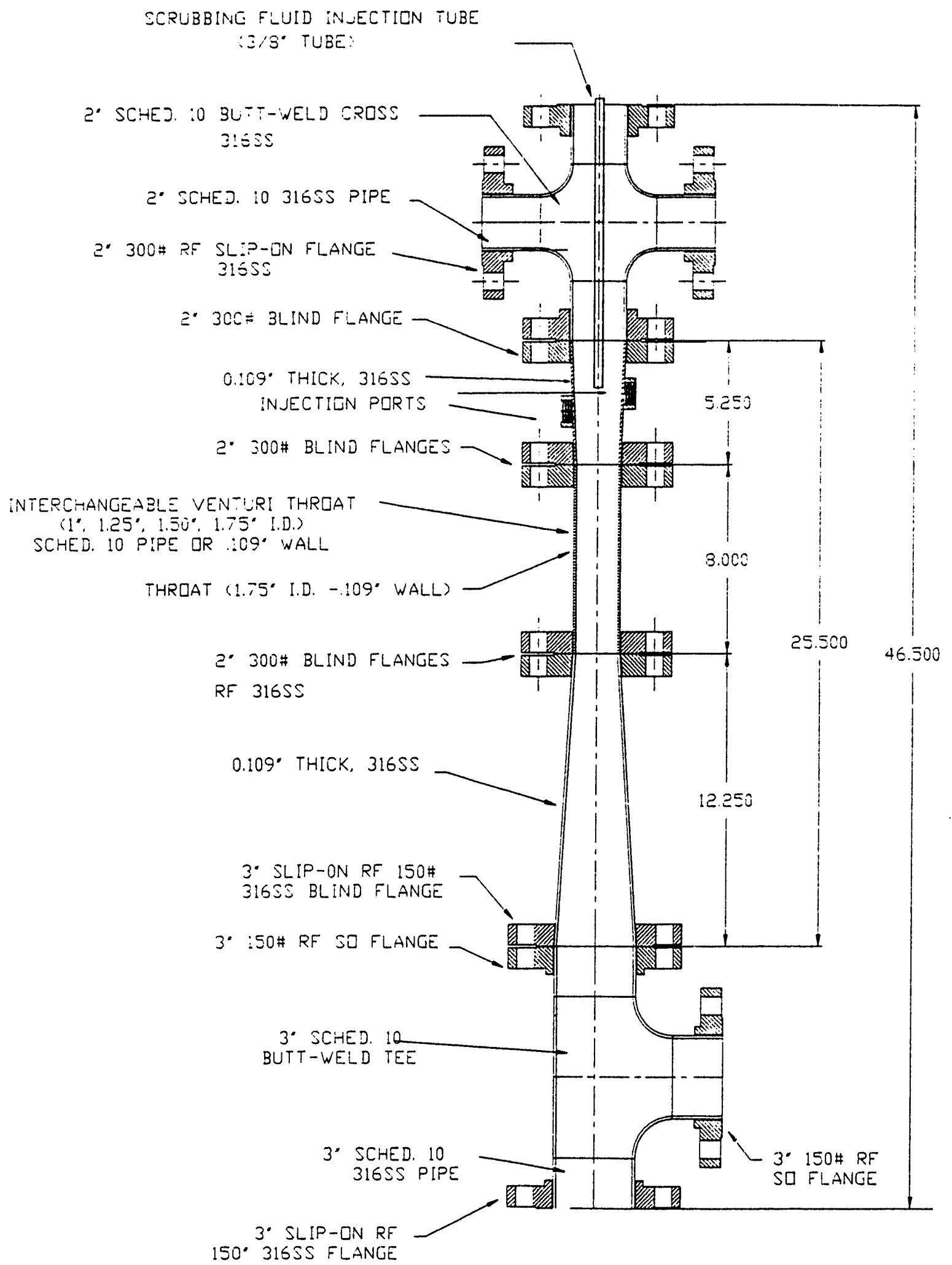

Figure 16. Venturi scrubber. 


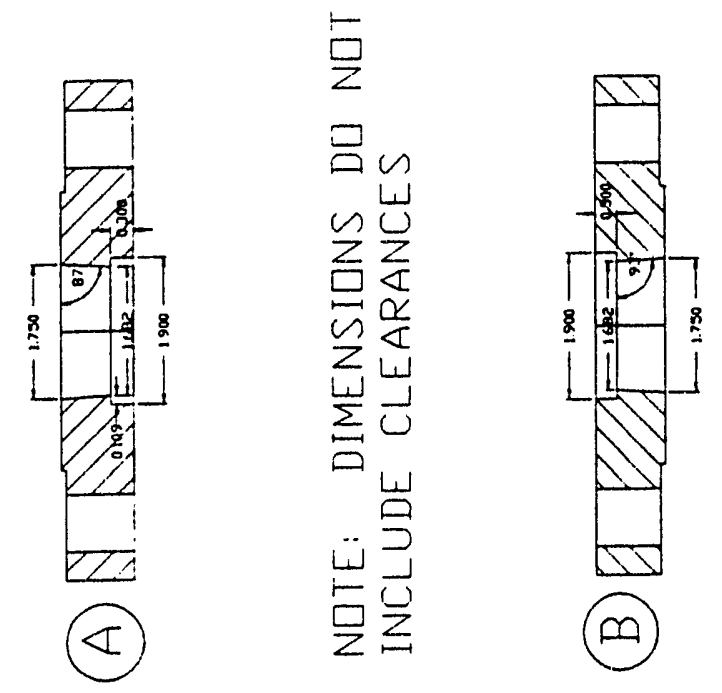

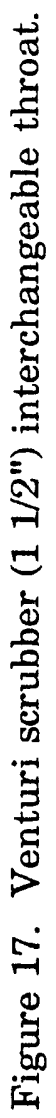

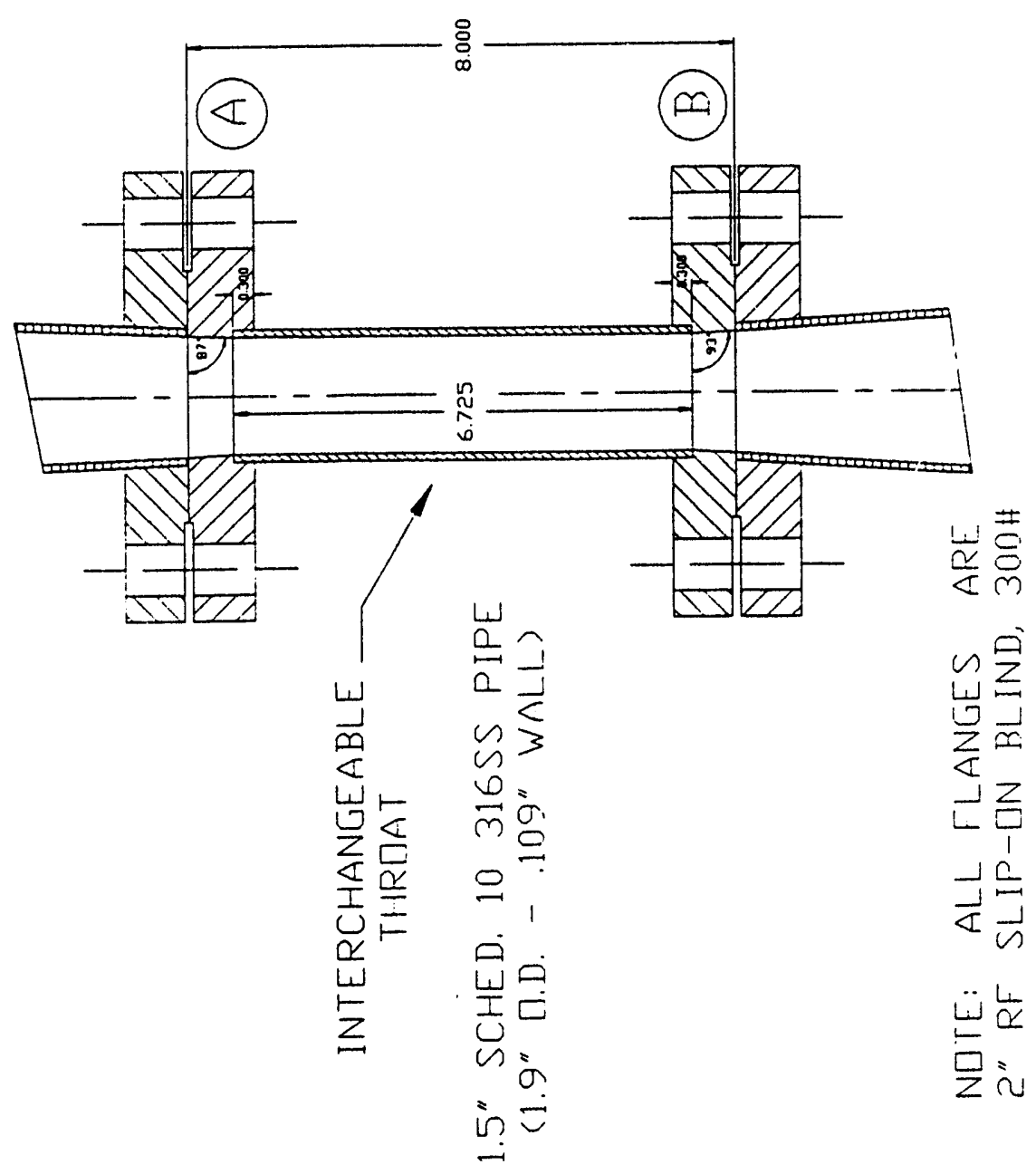




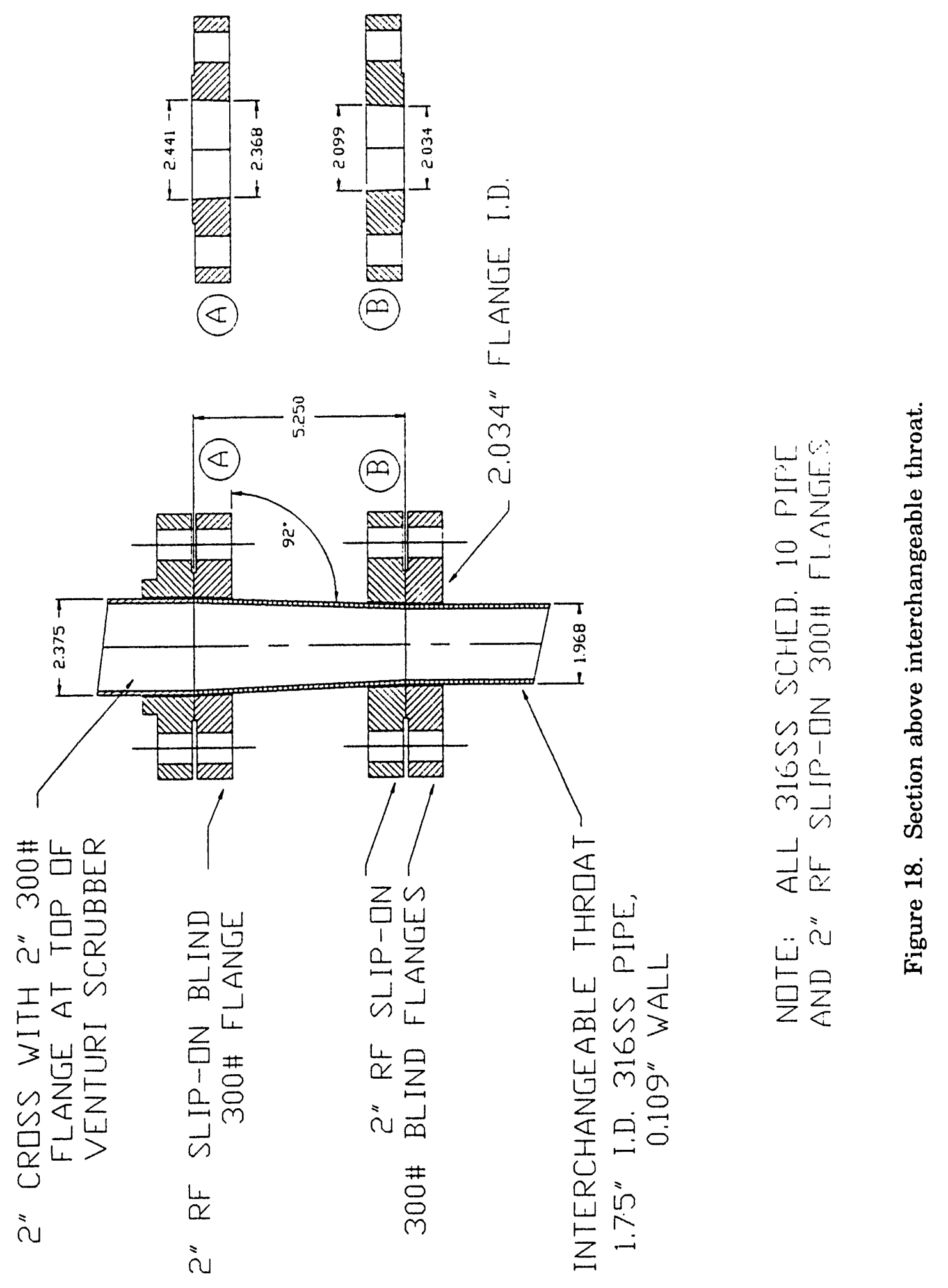



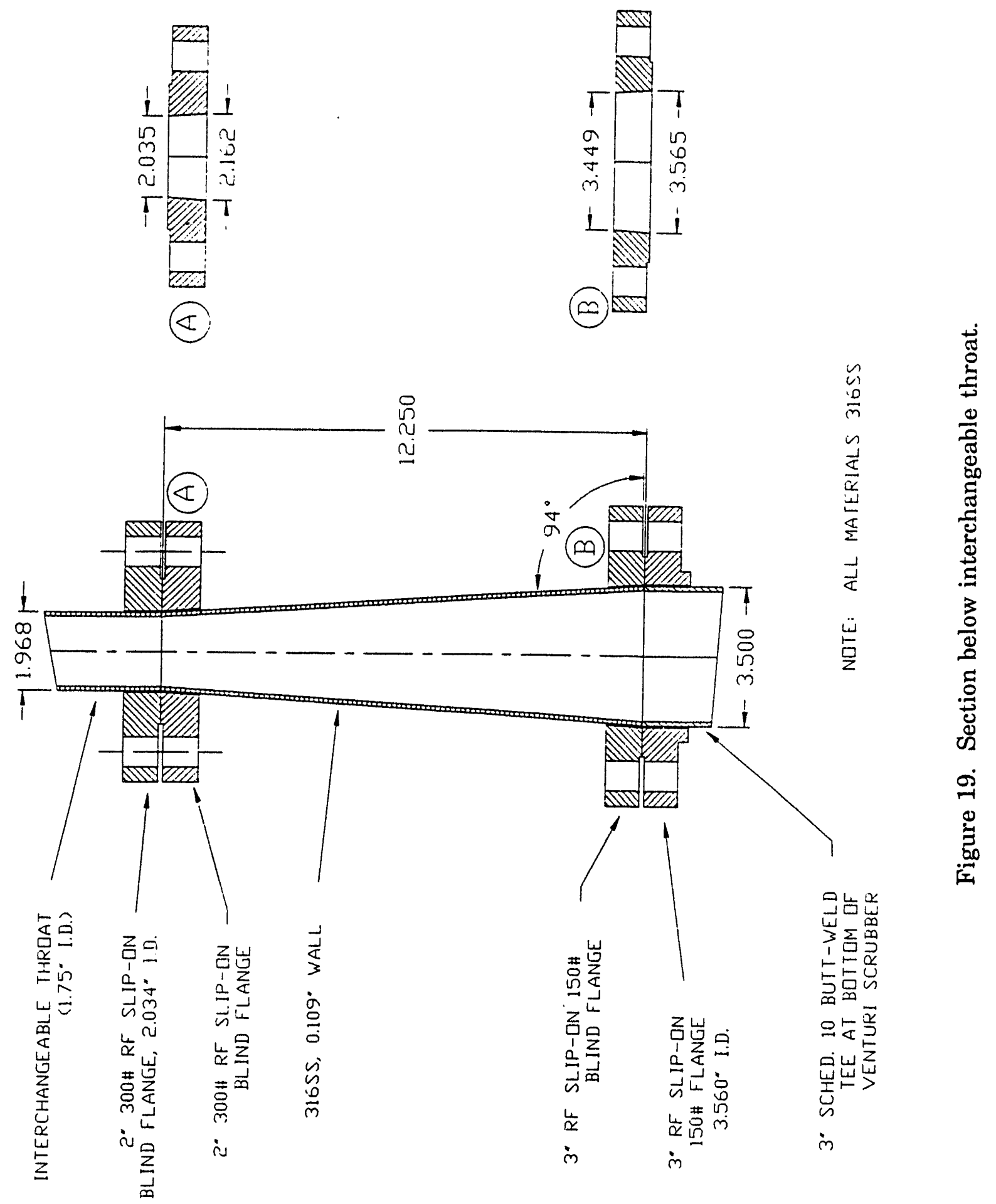

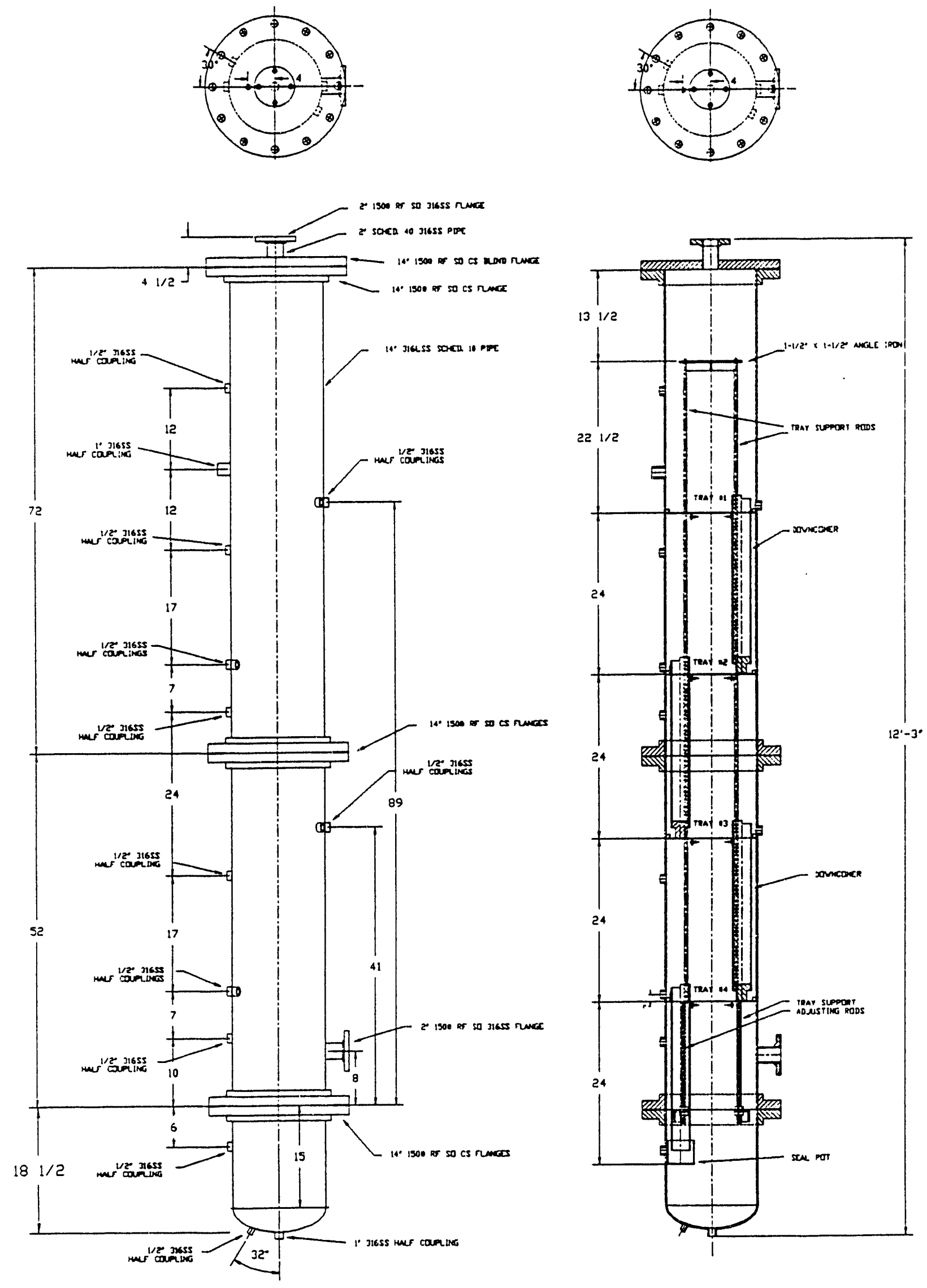

Figure 20. Sieve tower. 

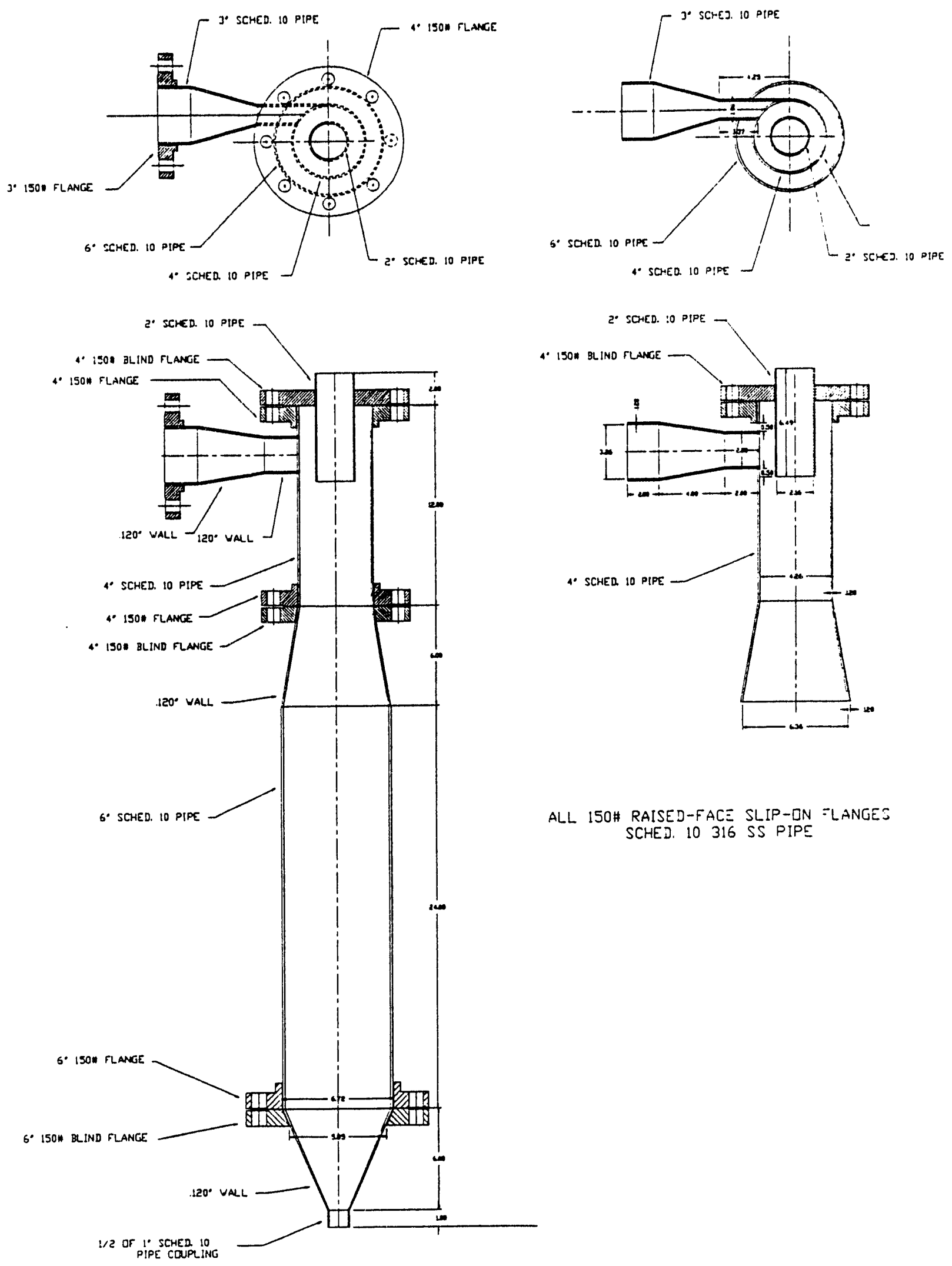

ALL 150\# RAISED-FACE SLIP-DN =LANGES SCHED. 10316 SS PIPE

Figure 21. Venturi scrubber 4" cyclone. 

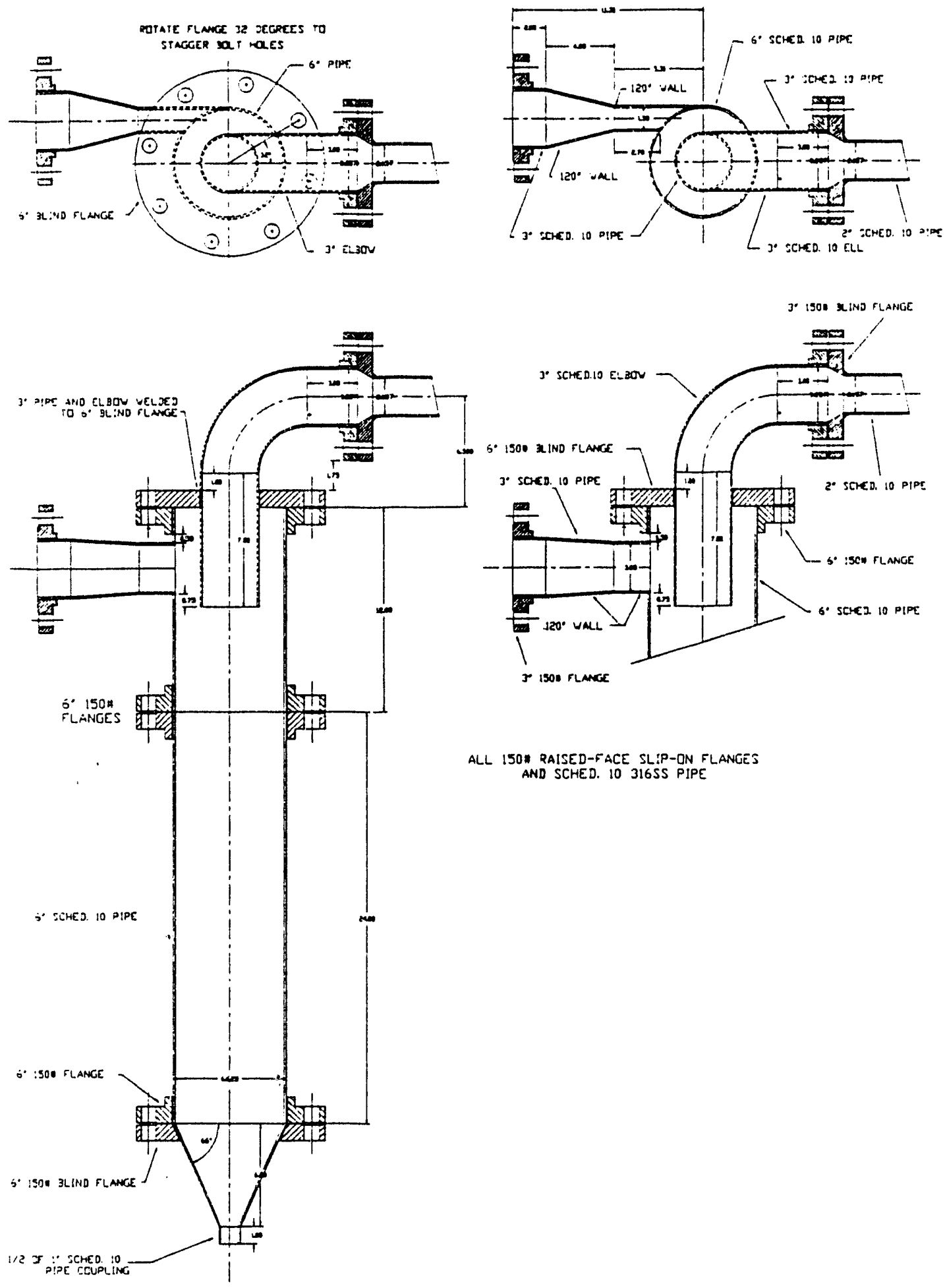

Figure 22. Venturi scrubber 6" cyclone. 


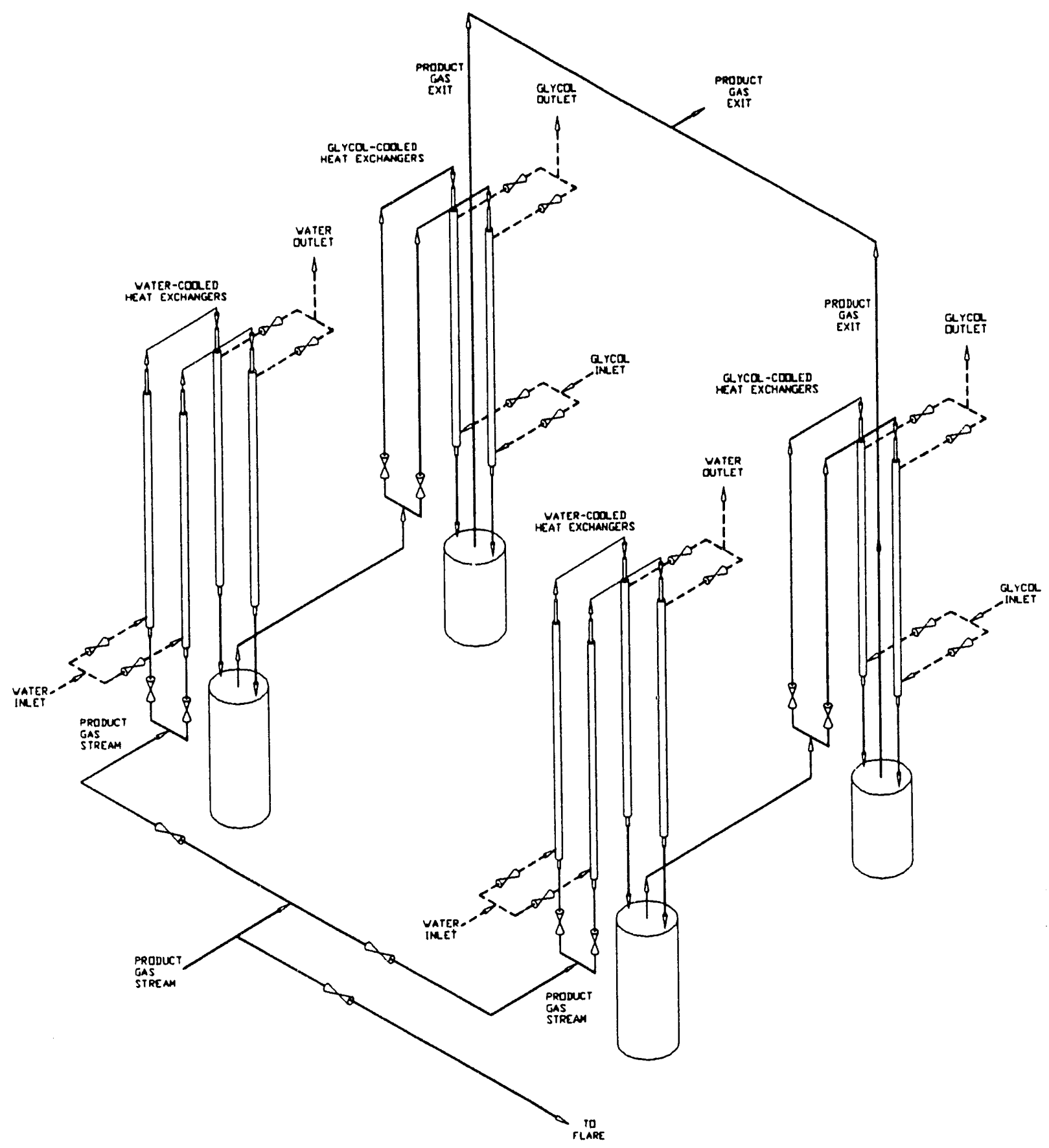

Figure 23. Calciner condensation train. 


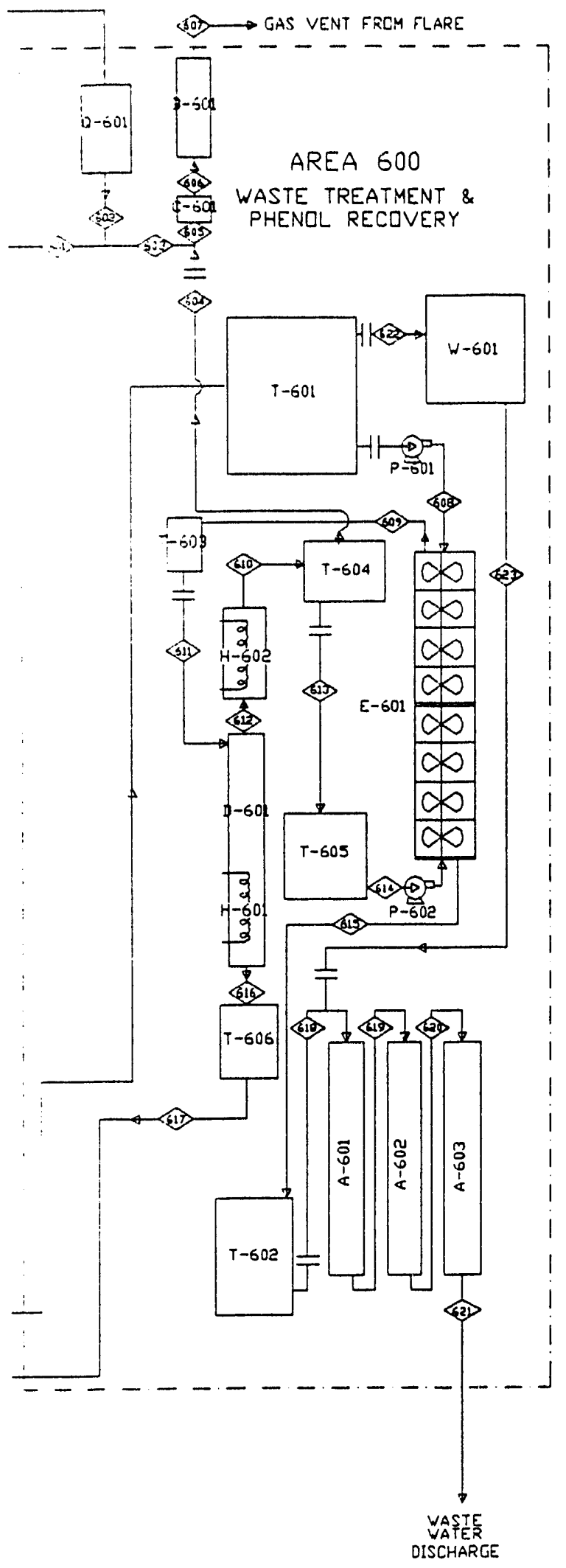

Figure 24. Wastewater cleanup and phenol recovery system. 
liquid-liquid extraction using diisopropyl ether (DIPE) as the solvent to remove phenols and most trace organics, possibly followed by treatment in granular activated carbon columns to produce water that meets discharge criteria. In a commercial process, the water could be recycled and used as process water (2). A letter from the Grand Forks, North Dakota, Department of Water \& Wastewater approving the EERC biochemical treatment process is contained in Appendix B.

The extract from the liquid-liquid extractor was distilled in a solvent recovery still to separate the DIPE from the crude phenol stream. The oil, light oil, and crude phenol streams were evaluated in upgrading studies. A large wastewater holding tank was included in the PRU scheme since wastewater treatment was not performed concurrently with mild gasification testing.

Vent gas from the wastewater treatment process is sent to a flare, as is raw gas from the carbonizer and calciner during start-up and scrubbed gas from the carbonizer and calciner condensation trains during operation. The flare operates at a flame temperature of $1800^{\circ} \mathrm{F}\left(982^{\circ} \mathrm{C}\right)$, with a typical residence time of 0.5 seconds (3). The emissions from the flare meet the requirements of the North Dakota State Health Department. The approval document for the flare system is contained in Appendix C.

\subsection{Characterization of the Co-Products from the CFBR and PRU}

\subsubsection{Characterization of CFBR Co-Products}

Several coals were processed in the $4-\mathrm{lb} / \mathrm{hr}$ CFBR, including both subbituminous and bituminous coals. The coals were run at a variety of temperatures and pressures, and the pyrolysis products were selectively characterized.

\subsubsection{Characterization of CFBR Char}

One of the target uses of the char from the mild gasification project is as a substitute for metallurgical coke. The analyses of chars produced from the gasification of Wyodak coal at $1100^{\circ} \mathrm{F}\left(590^{\circ} \mathrm{C}\right)$ and from the staged-gasification of Indiana No. 3 from $750^{\circ} \mathrm{F}\left(400^{\circ} \mathrm{C}\right)$ to $1290^{\circ} \mathrm{F}\left(700^{\circ} \mathrm{C}\right)$ in the CFBR are given in Table 2.

\subsubsection{Characterization of CFBR Liquids}

The characterization of the composite condensate from the staged-gasification of Indiana No. 3 in the CFBR is given in Table 3. Indanols, naphthols, and 2-ring phenolics were present in low concentrations in the composite condensate from Indiana No. 3. All other individual compounds were less than 2 wt\% of the product liquid. The normal alkanes were minor components of the composite condensate, with the maximum concentration at C13 of approximately $1 \mathrm{wt} \%$. The major compounds present in the condensate from the mild gasification of Wyodak in the CFBR are polar phenolics, as shown in Table 4. Relatively large amounts of phenol, cresols, xylenols, and trimethylphenols were produced at $840^{\circ} \mathrm{F}\left(450^{\circ} \mathrm{C}\right)$ and $930^{\circ} \mathrm{F}\left(500^{\circ} \mathrm{C}\right)$. 
TABLE 2

Wyodak and Indiana Feed Coal and Char Analyses

\begin{tabular}{|c|c|c|c|c|c|c|}
\hline \multirow{2}{*}{$\frac{\text { Coal }}{\text { Gasifier Unit }}$} & \multirow[t]{2}{*}{$\begin{array}{c}\text { Wyodak } \\
\text { Feed Coal } \\
\end{array}$} & \multicolumn{2}{|c|}{ Wyodak Char } & \multirow[t]{2}{*}{$\begin{array}{c}\text { Indiana } \\
\text { Feed Coal }\end{array}$} & \multicolumn{2}{|c|}{ Indiana Char } \\
\hline & & CFBR & PRU & & CFBR & PRU \\
\hline Run No. & \multicolumn{3}{|c|}{ MO20-21 } & \multicolumn{3}{|c|}{ MO72-402 } \\
\hline Temperature $\left({ }^{\circ} \mathrm{F} /{ }^{\circ} \mathrm{C}\right)$ & & $\begin{array}{c}1100 / \\
590\end{array}$ & $\begin{array}{c}1100 / \\
590\end{array}$ & & $\begin{array}{c}1300 / \\
700\end{array}$ & $\begin{array}{c}1100 / \\
590\end{array}$ \\
\hline \multicolumn{7}{|l|}{ Proximate Analysis (wt\%) } \\
\hline Moisture & 23.9 & 2.3 & 1.9 & 8.2 & 0.8 & 2.9 \\
\hline Volatile Matter & 33.8 & 15.1 & 15.4 & 37.1 & 8.5 & 12.7 \\
\hline Fixed Carbon & 37.9 & 71.6 & 72.1 & 42.8 & 72.0 & 65.4 \\
\hline Ash & 4.4 & 11.2 & 10.6 & 11.9 & 18.7 & 19.0 \\
\hline \multicolumn{7}{|l|}{ Ultimate Analysis (wt\%) } \\
\hline Hydrogen & 6.3 & 2.4 & 2.6 & 5.6 & 1.6 & 2.0 \\
\hline Carbon & 51.0 & 77.1 & 78.6 & 59.7 & 73.6 & 71.7 \\
\hline Nitrogen & 0.7 & 1.3 & 1.3 & 1.2 & 1.5 & 1.2 \\
\hline Sulfur, $\mathrm{mf}^{1}$ & 0.4 & 0.4 & 0.7 & 5.0 & 3.4 & 3.0 \\
\hline Oxygen $^{2}$ & 36.8 & 7.9 & 5.2 & 17.1 & 1.4 & 3.2 \\
\hline Ash & 4.8 & 11.2 & 11.7 & 11.9 & 18.7 & 19.0 \\
\hline Heating Value (Btu/lb), mf & 9,065 & 12,641 & 12,582 & & & \\
\hline \multicolumn{7}{|l|}{ Sulfur Forms ${ }^{s}$} \\
\hline Total Sulfur & & & & 5.1 & & 2.8 \\
\hline Organic & & & & 2.8 & & 2.6 \\
\hline Pyritic & & & & 1.2 & & 0.2 \\
\hline Sulfitic & & & & 1.1 & & 0.1 \\
\hline
\end{tabular}

Moisture-free basis.

Calculated by difference.

Analysis performed by Minnesota Valley Testing Labs, Bismarck, ND. Sulfur forms given on a moisture-free basis. 


\section{TABLE 3}

Characterization of the Composite Condensate from Staged Gasification of Indiana Coal in the CFBR (Run No. 70-225)

\begin{tabular}{|c|c|}
\hline Parameter/Constituent & \\
\hline $\mathrm{pH}$ & 4.09 \\
\hline Ammonia (total) & 75 ppm \\
\hline Ammonia (steam-strippable) & 31 ppm \\
\hline Cyanide (total) & $1.3 \mathrm{ppm}$ \\
\hline Sulfide & $<5 \mathrm{ppm}$ \\
\hline Thiosulfate & $3.0 \mathrm{ppm}$ \\
\hline Thiocyanate & $0.8 \mathrm{ppm}$ \\
\hline Chemical Oxygen Demand (COD) & 4590 ppm \\
\hline Biochemical Oxygen Demand $\left(\mathrm{BOD}_{5}\right)$ & 2040 ppm \\
\hline Phenol (4AAP) & 365 ppm \\
\hline Arsenic & $<50 \mathrm{ppb}$ \\
\hline Barium & $<0.2 \mathrm{ppm}$ \\
\hline Cadmium & $<0.02 \mathrm{ppb}$ \\
\hline Chromium & $<0.02 \mathrm{ppb}$ \\
\hline Lead & $<0.6 \mathrm{ppb}$ \\
\hline Mercury & $<3.0 \mathrm{ppb}$ \\
\hline Selenium & $6.1 \mathrm{ppb}$ \\
\hline Silver. & $<1.0 \mathrm{ppb}$ \\
\hline Compound: & Wt\% of Liquids \\
\hline Benzene & 2.77 \\
\hline Toluene & 0.62 \\
\hline Naphthalene & 0.79 \\
\hline Phenanthrene & 0.52 \\
\hline Phenol & 6.62 \\
\hline Cresols & $\begin{array}{l}4.07 \\
9.12^{a}\end{array}$ \\
\hline Xylenols & $\begin{array}{l}0.60 \\
0.67^{a} \\
4.89^{a} \\
2.04^{a} \\
1.85^{a}\end{array}$ \\
\hline $\mathrm{C} 3-\mathrm{POH}$ & $\begin{array}{l}0.94 \\
0.88^{\mathrm{a}} \\
1.02^{\mathrm{a}} \\
1.72^{\mathrm{a}}\end{array}$ \\
\hline
\end{tabular}

a Compound not identified. 
TABLE 4

Characterization of Wyodak Coal Condensate Composite from CFBR Tests

\begin{tabular}{|c|c|}
\hline Parameter/Constituent & \\
\hline $\mathrm{pH}$ & 7.73 \\
\hline Ammonia (total) & $448 \mathrm{ppm}$ \\
\hline Ammonia (steam-strippable) & $310 \mathrm{ppm}$ \\
\hline Sulfide & $<5 \mathrm{ppm}$ \\
\hline Thiosulfate & $15 \mathrm{ppm}$ \\
\hline Thiocyanate & 16 ppm \\
\hline Chemical Oxygen Demand (COD) & $18,300 \mathrm{ppm}$ \\
\hline Biochemical Oxygen Demand $\left(\mathrm{BOD}_{5}\right)$ & $15,700 \mathrm{ppm}$ \\
\hline Phenol (4AAP) & $1,210 \mathrm{ppm}$ \\
\hline Arsenic & $<10 \mathrm{ppb}$ \\
\hline Barium & $<50 \mathrm{ppm}$ \\
\hline Cadmium & $<1 \mathrm{ppb}$ \\
\hline Chromium & $<10 \mathrm{ppb}$ \\
\hline Lead & $<10 \mathrm{ppb}$ \\
\hline Mercury & $<0.6 \mathrm{ppb}$ \\
\hline Selenium & $20 \mathrm{ppb}$ \\
\hline Silver & $<1 \mathrm{ppb}$ \\
\hline Compound & Wt\% of Liquids \\
\hline Benzene & 1.1 \\
\hline Toluene & 0.3 \\
\hline Naphthalene & 2.3 \\
\hline Phenanthrene & 1.2 \\
\hline Phenol & 19.8 \\
\hline Cresols & 13.3 \\
\hline Xylenols & 4.2 \\
\hline $\mathrm{C} 13-\mathrm{C} 22$ & 7.7 \\
\hline Phytene & 0.7 \\
\hline $\mathrm{C} 23-\mathrm{C} 30$ & 3.3 \\
\hline
\end{tabular}

a Compound not identified. 


\subsubsection{Characterization of PRU Co-Products}

\subsubsection{Characterization of PRU Char}

The analyses of chars produced from the gasification of Wyodak and Indiana No. 3 at $1100^{\circ} \mathrm{F}\left(590^{\circ} \mathrm{C}\right)$ in the PRU are given in Table 2. Coarse char from the PRU process was sent to independent contractors for use in upgrading studies for the production of activated carbon and metallurgical coke substitutes.

\subsubsection{Characterization of PRU Liquids}

The liquids from the tar scrubber contain $85 \%-95 \%$ petroleum heavy oil, and the liquids from water scrubber $\# 2$ were $25 \%$ light oil and $75 \%$ water. The liquid products from the tar scrubbers and the water scrubbers were collected separately and stored in 55 . gallon barrels. Analyses of the liquids produced during runs using both the Western subbituminous and Eastern bituminous coals are presented in Table 5. The characteristics of the decant oil, fuel oil, and coal tar composite are given in Table 6.

\section{TABLE 5}

Analysis of Condensables from PRU Tests

\begin{tabular}{|c|c|c|c|c|c|c|c|}
\hline & & & \multicolumn{3}{|c|}{ Wyodak-P010 } & \multicolumn{2}{|c|}{ Indiana-P011 } \\
\hline & \#2 Diesel (\%) & $\begin{array}{c}\text { Decant Oil } \\
(\%)\end{array}$ & \multicolumn{3}{|c|}{ Total Liquids (\%) } & \multicolumn{2}{|c|}{ Total Liquids (\%) } \\
\hline 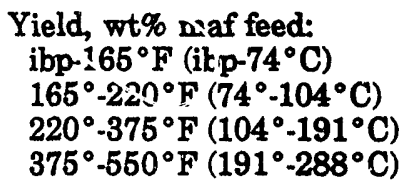 & $\begin{array}{r}2 \\
16 \\
82 \\
-\end{array}$ & $\begin{array}{r}. \\
16 \\
84\end{array}$ & & $\begin{array}{l}0 \\
1 \\
4 \\
5\end{array}$ & & 1 & $\begin{array}{l}1 \\
6 \\
1\end{array}$ \\
\hline \multirow[t]{2}{*}{ Total } & 100 & 100 & & 10 & & 1 & \\
\hline & & & $\begin{array}{c}\text { Tar } \\
\text { Scrubber }\end{array}$ & $\begin{array}{l}\text { Sieve } \\
\text { Tower }\end{array}$ & $\begin{array}{c}\text { Water } \\
\text { Scrubber }\end{array}$ & $\begin{array}{c}\text { Tar } \\
\text { Scrubber }\end{array}$ & $\begin{array}{c}\text { Water } \\
\text { Scrubber }\end{array}$ \\
\hline Yield, wt\% maf feed & & & Sample & 6.5 & 3.5 & & \\
\hline $\begin{array}{l}\text { Proximate Analysis, wt\% } \\
\text { Moisture } \\
\text { Volatile Matter } \\
\text { Fixed Carbon } \\
\text { Ash }\end{array}$ & & & $\begin{array}{r}0.4 \\
62.9 \\
31.8 \\
4.9\end{array}$ & & 13.9 & $\begin{array}{r}0.2 \\
49.6 \\
42.4 \\
7.9\end{array}$ & \\
\hline $\begin{array}{l}\text { Ultimate Analysis, wt\% } \\
\text { Carbon } \\
\text { Hydrogen } \\
\text { Nitrogen } \\
\text { Oxygen }{ }^{1}\end{array}$ & & & $\begin{array}{r}91.6 \\
3.0 \\
2.6 \\
1.5\end{array}$ & $\begin{array}{r}87.5 \\
10.6 \\
0.3 \\
0.7\end{array}$ & 1.6 & $\begin{array}{r}89.6 \\
2.6 \\
2.9 \\
2.2\end{array}$ & \\
\hline $\begin{array}{l}\text { Sulfur, wt\% } \\
\text { GC/AED } \\
\text { Leco }^{2}\end{array}$ & 0.5 & $\begin{array}{l}2.1 \\
1.9\end{array}$ & $\begin{array}{l}0.3 \\
1.3\end{array}$ & $\begin{array}{l}0.5 \\
0.9\end{array}$ & 0.3 & 2.7 & $\begin{array}{l}0.8 \\
1.5\end{array}$ \\
\hline Coal Fines, wt $\%^{3}$ & & & 29.6 & & & 36.4 & \\
\hline Melting Point, ${ }^{\circ} \mathrm{F} /{ }^{\circ} \mathrm{C}$ & & & $185 / 85$ & & & & \\
\hline
\end{tabular}

1 Oxygen by difference.

2 maf basis, Leco sulfur percentage used in ultimate analysis.

$s$ Determined by comparison of cyclone ash and scrubber liquids. 
TABLE 6

Decant Oil, Fuel Oil, and Coal Tar Composite Characterization

\begin{tabular}{cc}
\hline Constituent/Parameter & Composition \\
\hline $\mathrm{Pb}$ & $<500 \mathrm{ppb}$ \\
$\mathrm{As}$ & $3.0 \mathrm{ppm}$ \\
$\mathrm{Ag}$ & $<50 \mathrm{ppb}$ \\
$\mathrm{Se}$ & $<150 \mathrm{ppb}$ \\
$\mathrm{Ba}$ & $<0.5 \mathrm{ppm}$ \\
$\mathrm{Hg}$ & $<150 \mathrm{ppb}$ \\
$\mathrm{Cd}$ & $<0.25 \mathrm{ppm}$ \\
$\mathrm{Cr}$ & $<0.25 \mathrm{ppm}$ \\
Ignitability & $<140^{\circ} \mathrm{F}$ \\
\hline
\end{tabular}

\subsubsection{Gas Characterization}

The gas from the process was sent to a flare. The compositions and flow rates of gas from tests with Wyodak and Indiana No. 3 are shown in Table 7.

TABLE 7

Gas Composition from PRU Tests with Wyodak and Indiana No. 3

\begin{tabular}{lcc}
\hline \multicolumn{1}{c}{ Coal: } & Wyodak & Indiana \\
\hline Run Temperature $\left({ }^{\circ} \mathrm{F} /{ }^{\circ} \mathrm{C}\right)$ & $1100 / 600$ & $1300 / 700$ \\
Composite (mf), wt\% & & \\
$\mathrm{N}_{2}$ & 88.3 & 94.3 \\
$\mathrm{CO}_{2}$ & 6.5 & 5.6 \\
$\mathrm{CO}$ & 0.8 & $144 \mathrm{ppm}$ \\
$\mathrm{H}_{2} \mathrm{~S}$ & 0.0 & $72 \mathrm{ppm}$ \\
$\mathrm{CH}_{4}$ & 1.0 & $216 \mathrm{ppm}$ \\
$\mathrm{H}_{2}$ & 3.4 & $36 \mathrm{ppm}$ \\
Flowrate, scfh & 5953 & 5521 \\
\hline
\end{tabular}




\subsection{DECONTAMINATION AND DISASSEMBLY OF THE CFBR AND PRU}

\subsection{Decontamination and Disassembly of the CFBR}

Prior to disassembly of the CFBR, accumulated tar residue must be removed from the reactor, piping and tubing lines, and the condenser vessels. Based on experience from the CFBR mild gasification tests, lacquer thinner must be pumped through the unit for at least one hour to remove the residual tar. The lacquer thinner wash may be followed by a water wash.

The CFBR will be disassembled after the system has been thoroughly flushed out. The following equipment must be disassembled and removed for storage:

1. Superheater

2. Water supply pump

3. Coal feed system (hopper, auger, ball feeder, valves)

4. Reactor

5. Cyclone and fines catch pot

6. Condensers (water lines, glycol bath, condenser pots, valves)

7. Gas meter

After the process piping and reactor have been disassembled, the equipment will be inspected for tar residues and flushed again with acetone or lacquer thinner, if necessary. All solvent used for cleaning the system will be collected for recycle or proper disposal. Handling and disposal of the solvent will be properly documented. The equipment will be removed and stored for future use.

The building housing the CFBR will be returned to its original configuration after the equipment is decontaminated and removed. Necessary structural repairs to the roof, floors, and walls will be completed.

\subsection{Decontamination and Disassembly of the PRU}

Appendix A contains the equipment list for the PRU. The disassembly and decontamination for each piece of equipment will depend on its use in the mild gasification process.

The following are the five levels of contamination in the mild gasification unit:

1. Equipment which was not contacted by coal or the products of mild gasification and, therefore, requires no decontamination. This includes the data acquisition system, instrument air compressor, and the instruments and equipment in the control room of the second floor of the gasification tower.

2. The ethylene-glycol coolant system including the ethylene glycol-cooled heat exchanger, the glycol heater system, the water-cooled heat exchangers next to the sieve tower and water scrubber $\# 2$.

3. Coal preparation equipment and the coal feed system including any equipment in contact with coal dust. 
4. Equipment contaminated externally with tar spilled or splattered during system upsets. This includes mainly the equipment, pipes, heat exchangers, tubing lines, pumps, valves, and meters located on the third floor of the gasification tower and also the walls on the third floor.

5. The gas quench and liquid separation trains which are contaminated with coal liquids containing a known carcinogen. This includes the condenser drain lines, gas vent line to the flare, and coal liquid containers.

Level 1 equipment does not require decontamination prior to disassembly. The coolant will be drained from the Level 2 equipment and stored for reuse. The equipment in Level 3 will be washed using high-pressure water. Coal fines will be separated from the wash water by settling followed by filtration and burned in the coal-fired boiler on the University of North Dakota (UND) campus. By reusing the water, less than 1000 gallons of water should be required for Level 3 decontamination.

Equipment contaminated externally with tar (Level 4) will be washed piece by piece with lacquer thinner after disassembly of the PRU. Proper health and safety practices must be followed by the personnel involved in the cleanup operation. Care must be taken to avoid ingestion, inhalation, or prolonged skin contact of the coal tars and lacquer thinner.

Equipment contaminated internally by accumulation of residual tar or oil (Level 5) will be flushed section by section with lacquer thinner. The equipment will be washed with solvent both before and after disassembly to ensure that all tar has been removed from the piping, pumps, gas quench condensers, light tar condensers, and drain lines. The coal tars will be separated from the solvent and incinerated.

After decontamination and disassembly of the PRU, the remaining equipment will be cleaned externally. All equipment, valves, pumps, and heat exchangers will be stored for reuse, and the building housing the PRU will be restored to its original condition. 


\subsection{DISPOSAL OF CO-PRODUCTS}

\subsection{Disposal of CFBR Co-Products}

\subsubsection{CFBR Char}

Char was the major product of the mild gasification process, as shown in Table 8. Much of the char was shipped to independent contractors and used in upgrading studies. Disposal of the remaining char depends on its sulfur content. As shown in Table 2, the sulfur content of the Wyodak char $(0.38 \mathrm{wt} \%)$ is considerably less than the sulfur content of the Indiana char (3.86 wt\%). The Wyodak char was burned in UND's coal-fired boiler; however, because of its higher sulfur content, the Indiana char was disposed in an approved landfill. The amount of material produced and the amount remaining for disposal from the CFBR tests are shown in Tables 9 and 10, respectively.

\subsubsection{CFBR Liquids}

The condensate/water from the CFBR tests was treated in the EERC biochemical treatment unit. The overflow from the unit (Tables 3 and 4) meets the requirements of the City of Grand Forks, North Dakota, Department of Water \& Wastewater and is discharged to the municipal water treatment plant. Residual sludge from the EERC wastewater treatment unit will be burned in UND's coal-fired boiler. Waste lacquer thinner and lacquer thinner/water mixture were stored in 55-gallon barrels, which will be shipped to a hazardous waste facility for proper disposal.

The tar/oil produced from tests in both the CFBR and PRU may be useful as a briquette binder. It is being tested for use in the production of charcoal briquettes in a separate research project at the EERC.

\subsection{Disposal of PRU Co-Products}

\subsubsection{PRU Char}

The coarse char, 1/4-25 mesh, from the drain leg of the PRU reactor was the desired product and was shipped to independent contractors for further testing. The char fines, 25 mesh, were collected in the primary and secondary cyclones. As for the char from CFBR, the Wyodak char fines will be burned in UND's coal-fired boiler and the Indiana char fines will be landfilled. The amount of material produced and the amount remaining for disposal from the PRU tests are shown in Tables 9 and 10, respectively.

\subsubsection{PRU Liquids}

The wastewater from the PRU which was contaminated with lacquer thinner, acetone, and other chemicals from cleaning the system was not treated in the EERC biochemical treatment unit. 
TABLE 8

Mild Gasification Product Yields (wt\% maf coal feed)

\begin{tabular}{lccccc}
\hline Coal: & Wyodak & Wyodak $^{\mathrm{a}}$ & Wyodak $^{\mathrm{b}}$ & Indiana & Indiana \\
Gasifier Unit: & CFBR & PRU & PRU & CFBR & PRU \\
\hline Gas & 29 & 35 & 41 & 12 & 14 \\
Water & -- &.- & $-\cdots$ & 5 & 5 \\
Condensables & 10 & 10 & 10 & 18 & 18 \\
Char & 61 & 55 & 49 & 65 & 63 \\
\hline
\end{tabular}

a No internal combustion.

b Limited internal combustion.

TABLE 9

Yield of Products from CFBR and PRU Tests

\begin{tabular}{lrrrr}
\hline \multicolumn{1}{c}{ Coal: } & \multicolumn{2}{c}{ Wyodak } & \multicolumn{2}{c}{ Indiana No. 3 } \\
Gasifier Unit: & CFBR & PRU & CFBR & PRU \\
\hline Material & & & & \\
Char, lb & 3,000 & 10,800 & 500 & 5,000 \\
Liquids, gal & 225 & $2,010^{\mathrm{a}}$ & 37 & $2,870^{1}$ \\
Tar/Oil, gal & 78 & $481^{\mathrm{b}}$ & 20 & $700^{2}$ \\
Gas, scfh & 542,000 & $2,609,000$ & 35,000 & 350,000 \\
Solvent Used, gal & 30 & 150 & 10 & 100 \\
\hline
\end{tabular}

- Organic liquid and water.

b Tar/oil only.

TABLE 10

Material Remaining for Disposal from CFBR and PRU Tests

\begin{tabular}{lcccc}
\hline \multicolumn{1}{c}{ Coal: } & \multicolumn{2}{c}{ Wyodak } & \multicolumn{2}{c}{ Indiana No. 3 } \\
Gasifier Unit: & CFBR & PRU & CFBR & PRU \\
\hline Material & & & & \\
Char, lb & 0 & 0 & 0 & 0 \\
Liquids, gal & 0 & 0 & 0 & 0 \\
Tar/Oil, gal & 0 & 50 & 0 & 50 \\
Solvent Used, gal & 30 & 150 & 10 & 100 \\
\hline
\end{tabular}


Wastewater that was not contaminated with solvents was treated in the EERC biotreatment unit. The unit removes biodegradable organics from wastewater and, therefore, it is an effective way of treating wastewater from the mild gasification of coal. Table 11 summarizes the average constituent removals from the biochemical treatment of the Indiana mild gasification process liquids. Waste tar/oil/diesel fuel was burned in the University of North Dakota boiler facility. The permit from the North Dakota State Health Department is contained in Appendix D.

\subsubsection{Gas}

The emissions from the PRU flare during the mild gasification of Wyodak and Indiana coals were approved by the North Dakota State Health Department. The analyses of the gases sent to the flare during testing were given in Table 5 .

\section{TABLE 11}

Average Constituent Removals from the Biochemical Treatment of Indiana No. 3 Mild Gasification Process Condensate

\begin{tabular}{lccc}
\hline \multicolumn{1}{c}{ Parameter } & Influent $(\mathrm{mg} / \mathrm{L})$ & Effluent $(\mathrm{mg} / \mathrm{L})$ & Percent Removal \\
\hline BOD $_{5}$ & 1720 & 54 & 96.9 \\
COD & 4590 & 2320 & 49.5 \\
Phenol (4AAP) & 315 & 23 & 92.7 \\
Ammonia & 181 & 165 & 8.8 \\
\hline
\end{tabular}




\subsection{COST AND SCHEDULE OF DECONTAMINATION, DISASSEMBLY, AND DISPOSAL}

The cost of the disposal of all products was paid for under the existing contract. The lacquer thinner disposal cost will be recovered under the CFBR and PRU maintenance cost center and will be completed prior to the termination of the contract. The estimated costs associated with the decommissioning of the CFBR and PRU are given in Appendix E. Rather than decommission the units, title transfer for the units has been requested by the EERC. If the units are to be decommissioned in the future, the EERC will assume the associated costs. Decommissioning the units would require approximately two months. 


\subsection{REFERENCES}

1. Boley, C.C.; Fegley, M.M. (1977). "Design and Operation of Two Refractory-Lined, Internally Heated, Entrained-Bed Carbonizers," NTIS: GFERC/RI-77/1.

2. Energy and Environmental Research Center (1989). "Bench-Scale Biological Treatment of Wastewater Produced from the Mild Gasification of Indiana Coal," Technical Report.

3. John Zink Company (1989). Test Flare Technical Summary, John Zink File No. F903-012CH. 


\section{APPENDIX A}

\section{PRU MILD GASIFICATION SYSTEM EQUIPMENT LIST}


Steam Boiler

Steam Superheater

Boiler Feedwater Treatment

Sparge Tank

Dowtherm System

Carbonizer

Carbonizer Feed Hopper

Carbonizer Feeder

Carbonizer Flue Gas Generator

Primary Carbonizer Cyclone

HV Char Storage Bin

Secondary Carbonizer Cyclone

Char Fines Collection Bin \#1

Calciner

Calciner Feed Hopper

Calciner Feeder

Calciner Flue Gas Generator

Calciner Cyclone

LV Char Storage Bin

Secondary Carbonizer Cyclone

Char Fines Collection Bin \#2

Tar Venturi Scrubbers

Tar Cooler

Tar Quench Circulation Pump

Venturi Scrubber Cyclone Heater \#1

Water Venturi Scrubber

Tar Oil Cooler

Oil/Water Circulation Pump \#1

Venturi Scrubber Cyclone Heater \#2

Oil Sieve Tower

Oil Cooler

Oil Quench Circulation Pump

Venturi Scrubber

Oil/Water Cooler

Oil/Water Circulation Pump \#2

Tar Transfer Barrel Heater

Tar/Oil Transfer Barrel Heater

Tar Transfer Tank

Tar/Oil Transfer Tank

Oil/Water Transfer Tank \#1

Oil/Water Transfer Tank \#2

Tar Sample Vessel

Tar/Oil Sample Vessel

Oil/Water Sample Vessel

Condensate Transfer Pump 
Emergency Tar Quench Vessel

Flare

Flare Kinockout Pot

Wastewater Storage Tank

Wastewater Pump

Extraction Column

Spent Solvent Storage Tank

Solvent Condenser

Solvent Recovery Column

Solvent Recovery Reboiler

Crude Phenol Storage Tank

Clean Solvent Receiver Tank

Clean Solvent Feed Tank

Solvent Pump

Solvent Ext. WW Storage Tank

WW Polishing Absorber \#1, \#2, \#3

Activated Sludge Unit

\section{VALVES}

Area 200

Oxygen Flow Valve

Calciner Tempering Nitrogen Valve

Calciner Natural Gas

Boiler Pressure Valve

Carbonizer Transport Nitrogen Valve

Carbonizer Temporing Nitrogen Valve

Carbonizer Natural Gas

Carbonizer Steam Valve

Area 300

Plenum Vent

Carbonizer Star Feeder

Carbonizer Auger

Carbonizer Coal Hopper Nitrogen Valve

Area 400

Calciner Star Feeder

Calciner Auger

Calciner Coal Hopper Nitrogen Valve

Calciner Back Pressure Valve

Area 500

Tar Scrubber Recycle Pump

Tar Heat Exchanger Fan

Sieve Tower Heat Exchanger Water Valve

Sieve Tower Heat Exchanger Oil Valve

Water Scrubber 1 Heat Exchanger Water Valve

Water Scrubber 1 Heat Exchanger Oil Valve 
Water Scrubber 2 Heat Exchanger Water Valve

Water Scrubber 2 Heat Exchanger Oil Valve

Back Pressure Valve

Area 600

Main Natural Gas Makeup Valve

Calciner Air Valve

Carbonizer Air Valve

Corblin Compressor Valve

Calciner Steam Valve

Area 700

Filter 1 Valve

Filter 2 Valve

Secondary Cyclone Bypass Valve

Primary Exit Valve

Hot Gas Bypass Valve 


\section{APPENDIX B}

WASTEWATER TREATMENT APPROVAL DOCUMENT FROM THE DEPARTMENT OF WATER AND WASTEWATER, CITY OF GRAND FORKS, NORTH DAKOTA 


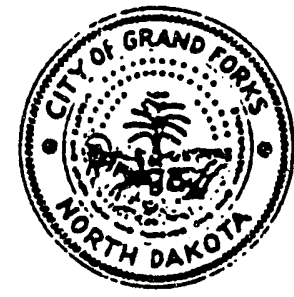

\section{CITY OF GRAND FORKS}

BOX 1518

GRAND FORKS. NORTH DAKOTA 58206.1518

DEPARTMENT OF WATER

Q WASTEWATER

$17011775 \cdot 0103$

May 12, 1989

Mr. Richard Shockey

Research Engineer

Energy and Research Center

PO Box B213

University Station

Grand Forks, ND 58202

Dear Mr. Shockey:

The City of Grand Forks will author1ze discharge of the efFluent From the Pilot scale activated sludge reactor.

This is only under the condition that the efeluent does not exceed the value of table 3 of the report.

If you should have any questions, please feel free to contact me.

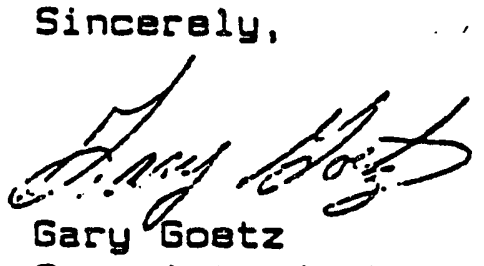

Superintendent

Wastewater Department

ce: Mr. Shea, Chemist

Mr. Johnson, ACE

EPA File

GG/dhb 
BENCH-SCAIE BIOLOGICAL TREATMENT OF WASTEWATER

PRODUCED FROM THE MIID GASIFICATION OF INDIANA COAL

\section{Introduction}

Mild gasification produces a contaminated process condensate stream that must be treated prior to reuse or discharge to the environment. Biological treatment removes biodegradable organics, such as $B O D_{5}$ and phenol, from wastewater. Ammonia oxidation (nitrification) will also occur if favorable conditions are maintained for the development of ritrifying bacteria. The goal of this study was to verify the treatability of mild gasification process condensates by the activated sludge process, without pretreatment.

\section{Wastewater Characteristics}

A sample of Indiana coal mild gasification process condensate was subjected to partial chemical characterization. Table 1 lists the results of characterization analyses.

The Indiana mild gasification wastewater was found to contain relatively low concentrations of organic constituents, compared to other gasification wastewaters. Heavy metals concentrations were relatively low. With the possible exception of cadmium and mercury, all were below drinking water standards.

\section{Eouipment Description}

A schematic diagram of the bench-scale activated sludge system is shown in Figure 1 . The mixed liquor aeration basin consisted of a 10-liter plexiglass tank with an operating volume of six liters. Biological solids within the aeration basin were maintained in suspension via mechanical mixing. oxygen was supplied to the system as filtered, humidified, compressed air, through a coarse bubble diffuser. Wastewater was fed to the aeration basin by a peristaltic pump. Mixed liquor flowed by gravity to a secondary clarifier with an operating volume of approximately 650 milliliters. Biological solids which settled to the bottom of the secondary clarifier were recycled back to the aeration basin three times every hour. supernatant and nonsettleable solids overflowed a central weir and were collected in an effluent storage tank. 


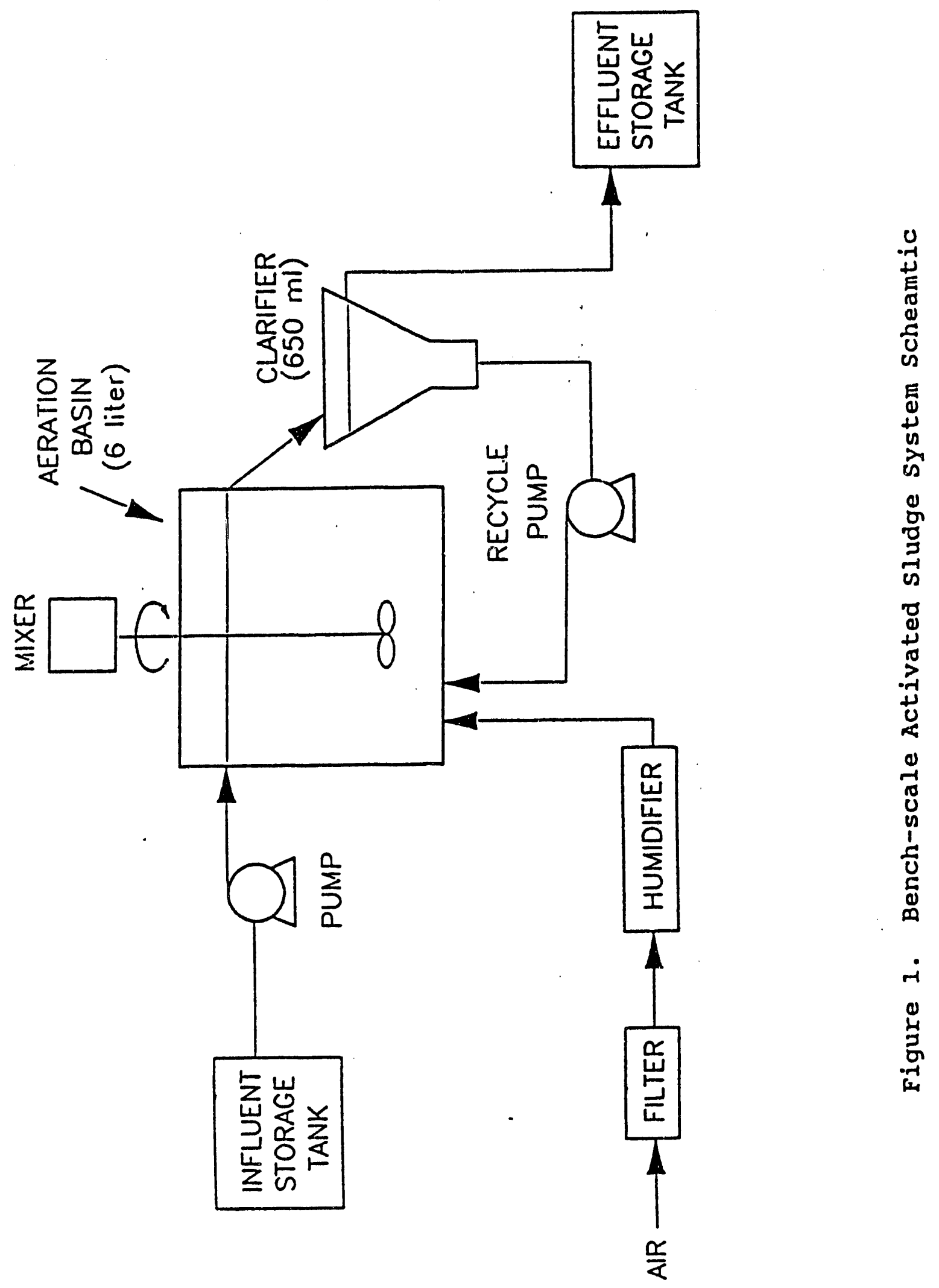


Table 1

RAW PROCESS CONDENSATE CHARACTERIZATION DATA (all values in $\mathrm{mg} / \mathrm{l}$, unless otherwise designated)

Parameter/Constituent

Indiana Mild Gas Process Condensate

\section{$\mathrm{pH}$}

Ammonia (total)

Ammonia (steam-strippable)

Cyanide (total)

sulfide

Thiocyanate

Thiosulfate

Chemical oxygen Demand (COD)

Biochemical Oxygen Demand $\left(B_{5} D_{5}\right)$

Phenol (4AAP)

Arsenic (ug/l)

Barium

Cadmium

Chromium

Iead

Mercury (ug/ $/ 2$ )

Selenium (ug/I)

Silver (ug/I)
4.09

75

31

2.3

$<5$

0.8

3.0

4590

2040

365

$<50$

$<0.2$

$<0.02$

$<0.02$

$<0.6$

$<3$

6.1

$<1$

\section{operation}

The bench-scale activated system began operation on Indiana mild gasification process condensate on March 13, 1989. The reactor was seeded with mixed liquor from a reactor treating solvent extracted and steam stripped gas liquor from a Iurgi gasifier. The reactor was fed mild gasification wastewater diluted with pretreated Iurgi wastewater with decreasing dilutions over the period of approximately one week. The low $\mathrm{pH}$ of the influent stream required adjustment to 7.0 using a $1: 1$ solution of sulfuric acid prior to being fed to the reactor. The reactor was continued 
in operation for an additional week for acclimation and stabilization with undiluted mild gasification condensate. Sampling and analysis for the evaluation of treatability performance was conducted during the third week of operation. The system was taken out of operation on April 1, 1989 due to limited availability of Indiana mild gasification process condensate.

Activated sludge process parameters were calculated in order to monitor system operation. The principal process control parameters for an activated sludge system are the solids retention time (SRT), the hydraulic retention time (HRT), the mixed liquor suspended solids (MISS) concentration, and the food-tomicroorganism $(F / M)$ ratio. Among these, the two that were used to control the bench-scale activated sludge system were the HRT and SRT. The HRT was regulated by adjusting the influent feed rate in conjunction with the aeration basin operating volume. The SRT was controlled through volumetric wasting of mixed liquor in relation to the mass of mixed liquor volatile suspended solids and the mass of volatile suspended solids lost to the effluent each day. In addition to the process control described above, routine testing and maintenance procedures were followed. These included measuring flow rates, $\mathrm{pH}$, temperature, mixed liquor dissolved oxygen concentration, mixed liquor solids settleability, and mixed liquor dissolved oxygen uptake rate.

\section{Results and Discussion}

Table 2 summarizes average operating parameters and conditions during the treatability study. Organic parameters used to evaluate treatability included $B O D_{5}, C O D$, and phenol. Activated sludge treatment at a 10-day solids retention time resulted in a 97 percent $B O D_{5}$ removal from an average of $1715 \mathrm{mg} / \mathrm{l}$ influent concentration to $54 \mathrm{mg} / \mathrm{l}$ in the effluent. COD was reduced from $4590 \mathrm{mg} / \mathrm{l}$ to $2320 \mathrm{mg} / \mathrm{l}$, a 50 percent removal efficiency. A 93 percent phenol reduction was achieved, with influent and effluent concentrations of $315 \mathrm{mg} / \mathrm{l}$ and $23 \mathrm{mg} / \mathrm{l}$, respectively. Ammonia was reduced from $181 \mathrm{mg} / \mathrm{l}$ to $165 \mathrm{mg} / \mathrm{l}$. The slight ammonia removal through the system can be attributed entirely to air stripping and biological nitrogen requirements. 
Table 2

OPERATING PARAMETERS DURING ACTIVATED SLUDGE TREATMENT OF INDIANA MILD GASIFICATION PROCESS CONDENSATE

\begin{tabular}{lcc} 
Parameter & Units & Value \\
\hline HRT & days & 2.9 \\
SRT & days & 10.2 \\
F/M & g BOD removed/ & 0.45 \\
MLVSS & MLVSs/day & \\
MLSS & $\mathrm{mg} / \mathrm{l}$ & 1290 \\
Solids Settleability & $\mathrm{mg} / \mathrm{l}$ & 1390 \\
Sludge Volume Index & $\mathrm{ml} / \mathrm{l}$ & 67 \\
Oxygen Uptake Rate & $\mathrm{ml} / \mathrm{g}$ & 48.2 \\
& $\mathrm{mg} / \mathrm{l} / \mathrm{min}$ & 0.17 \\
\hline
\end{tabular}

Table 3 summarizes average constituent removals during treatability testing. Although high removal efficiencies were achieved during the abbreviated testing period, a considerable amount of organics (54 $\mathrm{mg} \mathrm{BOD}_{5} /$ liter) remained in the effluent. With a longer period of operation for acclimation and stabilization, a higher effluent quality would be expected as no apparent inhibition was observed during treatment. Approximately fifty percent of the chemical oxygen demand was accounted for in the effluent. Removal of these biorefractory organics would require tertiary treatment. These effluent polishing steps might include ozonation, activated carbon adsorption, or chemical coagulation and precipitation. Stringent discharge criteria may require further reduction of effluent ammonia. This may be accomplished through ion exchange using clinoptilolite, a naturaliy occurring zeolite. 
Table 3

AVERAGE CONSTITUENT REMOVALS DURING ACTIVATED SLUDGE TREATMENT OF INDIANA MILD GAS PROCESS CONDENSATE

\begin{tabular}{lccc} 
Parameter & $\begin{array}{c}\text { Influent } \\
(\mathrm{mg} / \mathrm{l})\end{array}$ & $\begin{array}{c}\text { Effluent } \\
(\mathrm{mg} / \mathrm{l})\end{array}$ & $\begin{array}{c}\text { Percent } \\
\text { Removal }\end{array}$ \\
\hline BOD $_{5}$ & 1720 & 54 & 96.9 \\
COD & 4590 & 2320 & 49.5 \\
Phenol (4AAP) & 315 & 23 & 92.7 \\
Ammonia & 181 & 165 & 8.8 \\
\hline
\end{tabular}

\section{Conclusions}

The conclusions from the brief treatability testing program on Indiana mild gasification process condensate are:

1. Pretreatment was not required to provide effective biological treatment.

2. Although high $B O D_{5}$ and phenol removal efficiencies were achieved, better removals can be anticipated with a longer operating period for acclimation and stabilization.

3. Depending upon effluent discharge regulations, further effluent polishing steps may be required to reduce refractory $C O D$ and ammonia concentrations. 
APPENDIX C

PRU FLARE REJECT GAS APPROVAL DOCUMENT FROM THE NORTH DAKOTA STATE HEALTH DEPARTMENT 


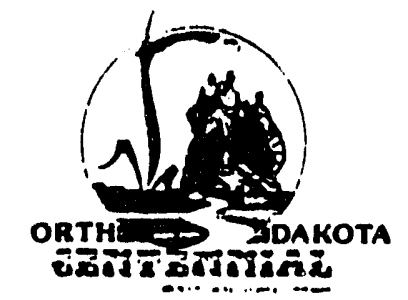

NORTH DAKOTA

STATE DEPARTMENT OF HEALTH

Page 1 of 3 AND CONSOLIDATED LABORATORIES

1200 Missouri Avenue

P.O. Box 5520

8lsmarck, North Dakola 58502.5520

AIR POLLUTION CONTROL

PERMIT TO CONSTRUCT

Pursuant to the Air Pollution Control Rules of the stiate of North Dakota and in reliance on statements and representarions contained in the Permit to Construct application of June 16 , 1989, the North Dakota State Department of Health and Consolidated Laboratories hereby grants the University of North Dakota Energy and Mineral Research Center a Permit to Construct for a $100 \mathrm{lb} / \mathrm{hr}$ pilot scale mild gasification process development unit in Grand Forks County, North Dakota. This Permit to Construct is subject to all applicable rules and orders now or hereafter in effect of the North Dakota state Department of Health and Consolidated Laboratories and to the conditions specified below:

1. The particulate emissions from the unit shall not exceed $0.551 \mathrm{lb} / \mathrm{hr}$ or 208 opacity. The opacity of emissions from the flare shall not exceed 20 \%. There shall be no discharge of any objectionable odorous air contaminants in excess of two odor concentration units outside the property boundary.

C-1 
2. This Permit shall in no way permit or authorize the maintenance of a public nuisance or danger to public health or safety.

3. The facility must comply with all state and local building, fire, and other applicable ordinances and codes.

4. Construction of the above described facility shall be in accordance with information provided in the Permit application as well as any plans, specifications and supporting data submitted to the Department. The Department shall be notified ten days in advance of any significant deviations from the specifications furnished. The issuance of this Permit to Construct may be suspended or revoked if the Department determines that a significant deviation from the plans and specifications Eurnished has been or is to be made.

5. Within thirty days after completion of construction, this Department must be notified so that a representative of this Department may inspect the facility for issuance of a Permit to Operate. 
6. Any violation of a condition issued as part of this approval to construct as well as any construction which proceeds in variance with any information submitted in the application, is regarded as a violation of construction authority and is subject to enforcement action.

7. This Permit to Construct is issued in reliance upon the accuracy and completeness of the information set forth in the application. Notwithstanding the tentative nature of this information, the conditions of this Permit herein become, upon the effective date of this Permit, enforceable by the Department pursuant to any remedies it now has or may in the future have, under the North Dakota Air Pollution Control Law, NDCC Chapter 23-25. Each and every condition of this Permit is a material part thereof, and is not severable.

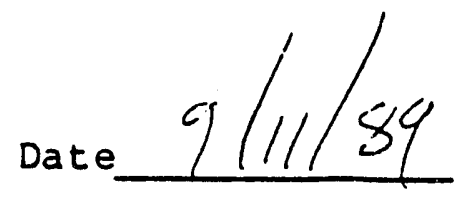

FOR THE NORTH DAKOTA STATE DEPARTMENT OE HEALTH AND CONSOLIDATED LABORATORIES

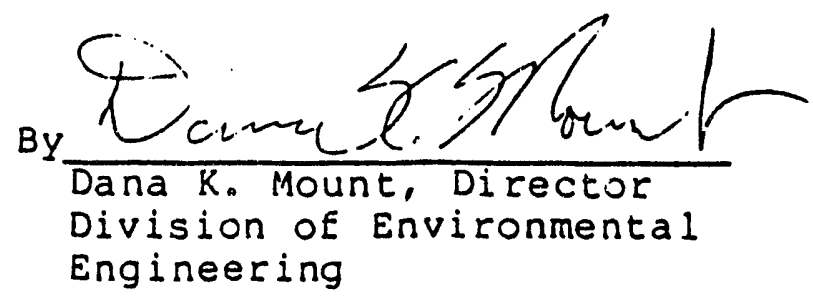




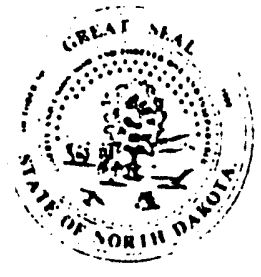

NORTH DAKOTA

STATE DEPARTMENT OF HEALTH

AND CONSOLIDATED LABORATORIES

Siate Capitol

600 E. Boulevard Avenue

Bismarck, North Dakota 58505-0200

ENVIRONMENTAL HEALTH SECTION

November 13, 1990

1200 Missourl Avenue

P.O. Box 5520

Bismarck, North Dakota 58502.5520

Mr. Ken L. Grohs

Facilities and Safety officer

UND Energy and Environmental

Research Center

Box 8213

University Station

Grand Forks, ND 58202-8213

Re: Air Pollution Control

Permit to Operate

Dear Mr. Grohs:

The Department issued a Permit to Construct on October 6, 1987 to the University of North Dakota Energy and Environmental Research Center for a circulating fluidized bed combustor to be located at the Research Center's facility in Grand Forks, North Dakota. On November 11, 1989\%. this Department issued a Permit to Construct for a mild gasification process development unit to be located at UNDEERC's facility in Grand Forks, North Dakota. The Research Center was inspected by Department personnel on September 13, 1990 and again on October 1, 1990.

Based on our review of the permit applications, the Air quality Effects Analyses, the Permits to Construct, and the results of the inspections, this Department hereby issues an amended Permit to Operate which includes the source units described above. The Department's issuance of this amended permit is contingent upon compliance with applicable sections of the North Dakota Air Poliution Control Rules as well as the attached conditions. You should read each condition carefully and become familiar with your responsibilities.

If you have any questions, please feel free to contact this Department.

Sincerely,

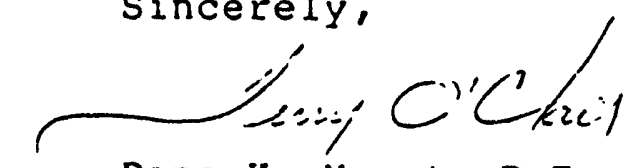

Dana K. Mount, P.E.

$\{$ Director, Division of

Environmental Engineering

DKM/DLU:sjk

Enc:

C-4 
Pursuant to Chapter 23-25 of the North Dakota Century Code, and the Air Pollution Control Rules of the state of North Dakota, and in reliance on statements and representations heretofore made by the owner designated below, a Permit to Operate is hereby issued authorizing such ownor to operate the source unit(s) at the location designated below. This Permit to Operate is subject to all applicable rules and orders now or hereafter in effect of the North Dakota State Department of Health and Consolidated Laboratories and to any conditions specified below:

\begin{tabular}{|c|c|c|}
\hline I. OW & er: & $\begin{array}{ll}\text { 2. } & \text { Permit Number } \\
& 078004\end{array}$ \\
\hline A. & $\begin{array}{l}\text { Jame } \\
\text { University of North Dakota } \\
\text { Energy \& Environmental } \\
\text { Research Center }\end{array}$ & $\begin{array}{l}\text { 3. Installation } \\
\text { University of North Dakota } \\
\text { Energy \& Environmental Research } \\
\text { Center }\end{array}$ \\
\hline B. & $\begin{array}{l}\text { Address } \\
15 \mathrm{~N} 23 \text { street } \\
\text { Grand Forks, ND }\end{array}$ & $\begin{array}{l}\text { 4. Installation Location } \\
\text { Grand Forks, ND } \\
\text { Grand Forks County }\end{array}$ \\
\hline
\end{tabular}

5. Expiration Date:

April 24, 1992

6. Source Unit(s):

A. Ash fouling furnace with a maximum burning capacity of $951 \mathrm{~b} / \mathrm{hr}$ pulverized coal or $150 \mathrm{lb} / \mathrm{hr}$ coal water slurry. Particulate emissions from the combustor are controlled by either an electrostatic precipitator or a baghouse.

B. Particulate test combustor with a maximum burning capacity of 85 $1 \mathrm{~b} / \mathrm{hr}$ pulverized coal. Particulate emissions from the combustor are controlled by either a research electrostatic precipitator or a test baghouse.

C. 18-inch square fluidized bed combustor, with a maximum burning rate of $500 \mathrm{lb} / \mathrm{hr}$ coal. Particulate emissions from the combustor are controlled by a Wheelabrator-Frye Model 108 ultra-jet baghouse with a design collection efficiency of 998 .

C-5 

D. 8-inch square fluidized bed combustor with a maximum burning rate of $100 \mathrm{lb} / \mathrm{hr}$ coal. Particulate emissions are controlled by a baghouse with a design efficiency of 998 .

E. A coal liquefaction system consisting of a microreactor system, batch autoclaves, continuous process unit, open tubular reactors and continuous stirred tank reactors. Gas from the continuous process unit is to be flared.

F. An incinerator for burning process gas from the process development unit for hydrothermal treatment of coal. The incinerator shall operate at a temperature of at least $1500^{\circ} \mathrm{F}$.

G. A pilot scale gas turbine simulator with a maximum burning rate of $200 \mathrm{lb} / \mathrm{hr}$ of coal-water slurry. Particulate emissions ara controlled by a 12.5 -inch diameter cyclone.

H. A $3.0 \times 10^{6}$ BTU/hr coal-fired circulating fluidized bed combustor (CFBC) test facility. Particulate emissions are controlled by a cyclone and/or baghouse.

I. A $100 \mathrm{lb} / \mathrm{hr}$ pilot scale mild gasification process development unit. Waste product gases are to be flared from a $15 \mathrm{ft}$. stack which is mounted on the gasification tower.

\section{CONDITIONS}

7. A. Emission limits from the operation of the source units identified in Item 6 of this Permit to Operate shall be as follows:

Air Contaminant

$\mathrm{SO}_{2}$

Opacity

odors

Particulate
Emission Limit

$31 \mathrm{~b} / 10^{6}$ Btu heat input 208

Not to exceed 2 o.c.u.* outside the property boundary

As specified in the application for a Permit to Construct or as specified in Chapter 33-15-05, whichever is more stringent.

*o.c.u. designates odor concentration units, which means the maximum number of standard units of odor-free air diluting a standard unit of odorous air so that a Department certified inspector or at least 50 percent of an odor panel can still detect an odor in the diluted mixture. 
B. All reasonable precautions shall be taken by the owner to prevent and/or minimize fugitive emissions to the outside air from the operation of the source unit(s) identified under Item 6 .

C. The owner described in Item 1 shall calibrate, maintain and operate a continuous monitoring system for sulfur dioxide emissions from the fluidized bed combustor (Source Unit 6.C.). The monitoring and recording shall be in accordance with the requirements for Notification and Record keeping Subsection 6 and Monitoring Requirements Subsection 11 of Section 33-15-12-01 of the Air Pollution Control Rules. The excess emission reports shall be submitted on a semi-annual basis.

D. The owner named in Item 1 shall operate the source unit(s) described in Item 6 of this permit in accordance with statements, representations, procedures and supporting data contained in the initial application, and any supplemental information or renewal applications submitted thereafter.

E. Any alteration, rebuilding, repairing, expansion, change in the method of operation, or change of location of the source which results in the emission of an additional type or greater amount of air contaminants or which results in an increase in the ambient concentration of any air contaminant must be reviewed and approved by the Department prior to the start of such alteration, rebuilding, repairing, expansion, change in the method of operation, or change of location.

F. This Permit to Operate shall in no way permit or authorize the maintenance of a nuisance or a danger to public health or safety.

G. This Permit to Operate shall be effective from the date of its issuance until the date specified in Item 5 , unless sooner suspended, revoked or surrendered. Application for renewal of this permit shall be submitted sixty $(60)$ days prior to such expiration date. The Department shall approve or disapprove the renewal of the Fermit to Operate within sixty (60) days of receipt of the renewal application.

H. The owner or operator shall obtain all Federal, state and local permits required for the operation of the facility and any experimentation, research or other activities conducted at the center.

I. This permit may not be transferred and is to be returned to the Department upon the destruction or change of ownership of the source unit(s), or upon expiration, suspension or revocation of this permit. 
J. This Permit to Operate is issued in reliance upon the accuracy and completeness of the information set forth in the application. The conditions of this permit herein become, upon the effective date of this permit, enforceable by the Department pursuant to any remedies it now has, or may in the future have, under the North Dakota Air Pollution Control Law, NDCC Chapter 23-25. Each and every condition of this permit is a material part thereof, and is not severable.

FOR THE NORTH DAKOTA STATE

DEPARTMENT OF HEALTH AND

CONSOLIDATED LABORATORIES
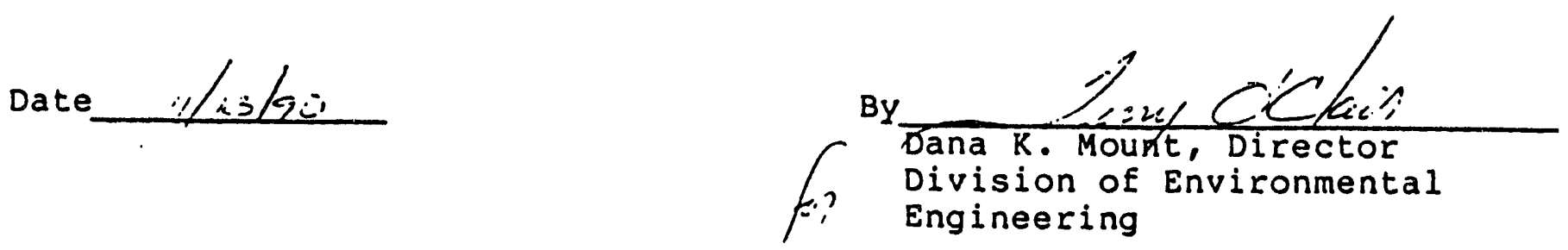


\section{APPENDIX D}

ORGANIC CONDENSABLE APPROVAL DOCUMENT FROM THE NORTH DAKOTA STATE HEALTH DEPARTMENT 
Mr. Dale P. Patrick

Occupational Safety and

Environmental Health office

P.O. Box 8275

University Station

Grand Forks, ND 58202

Dear Mr. Patyick:

This is in response to your letter dated January 25, 1991, concerning the use of a fuel oil/coal tar mixture as fuel for the boilers at the University heating plant. Since the fuel o1l/coal tar mixture is to be used for energy recovery purposes, 1ts use will be subject to 40 CFR 266 subpart $E$ and will be sultable for burning in the boilers provided it does not qualify as "offspecification" used oil.

The controls deemed appropriate by the Department for burning the fuel oll/coal tar mixture will be in accordance with conditions 7.D.3. through 7.D.8 of permit to Operate No. 730018. Additionally, no more than 200 gallons per hour of the oil mixture shall be burned in the heating plant boilers, and the source of the oil is restricted to that which is produced by the Energy Environmental and Mineral Research Center.

If there are any questions on this matter, please feel free to contact us.

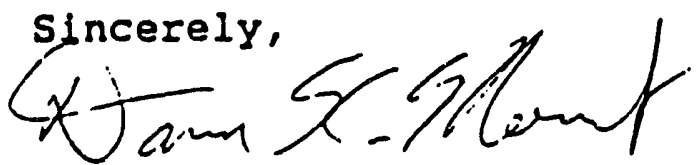

Dana K. Mount, P.E. Director, Division of Environmental Engineering

DKM/GLK : jf

XC: Leroy Sondrol

D-1

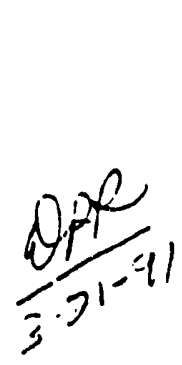

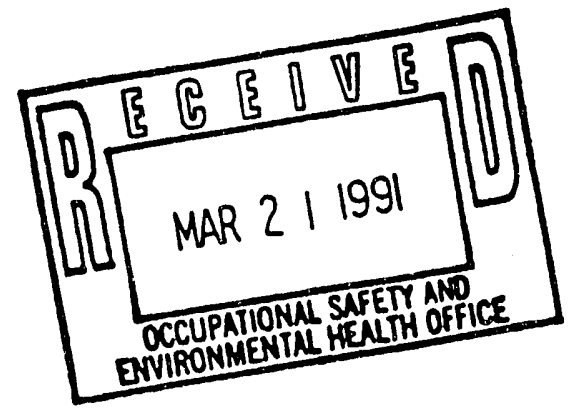


UNIVERSALTY O F (

OCCUPATIONAL SAFETY AND ENVIRONMENTAL HEALTH OFFICE BOX 8275. UNIVERSITY STATION CRAND FORKS. NORTH DAKOTA 58202

(701) 777.3341

Jasua $25,19 \Xi \$$

Dana $\ddot{x}$. Hourt, E.E. Division oE Environment三: Engineering Norti Dakota state Eept. of Heaith

120 ' Missouri Ave.

?.0. 20.. 5520

Bisniarcik, iND $5 a 502-5520$

Dear iana,

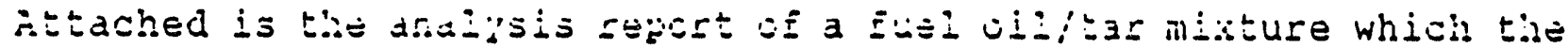
liniorsity wishes to use as boiler EuEi. Curfently, the lniversity has about 2,000 gallons of tijis materia: on hand. on a montily basis, an adoiticne- 50j-75j gsijons will be prociuces by the Energi

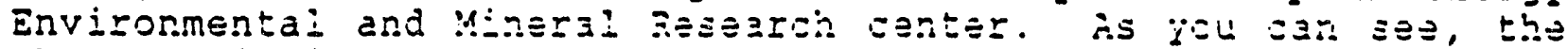

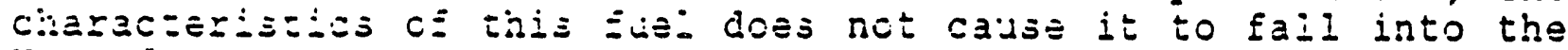
iazardous iaste caこegcr $\%$.

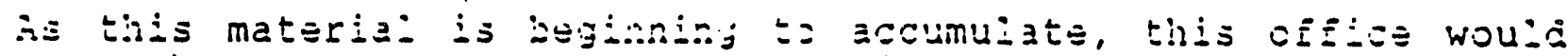

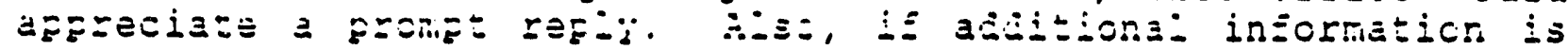

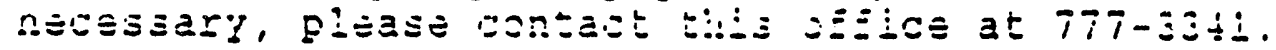

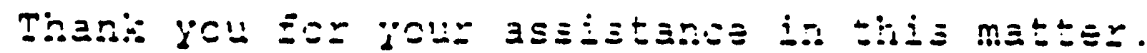

Sincereiy,

Nabe D- Patick

Daie ₹. 三atrici:

Director OE Saset

cc Join :̈encirikson

Ken Erohs

file - 2 


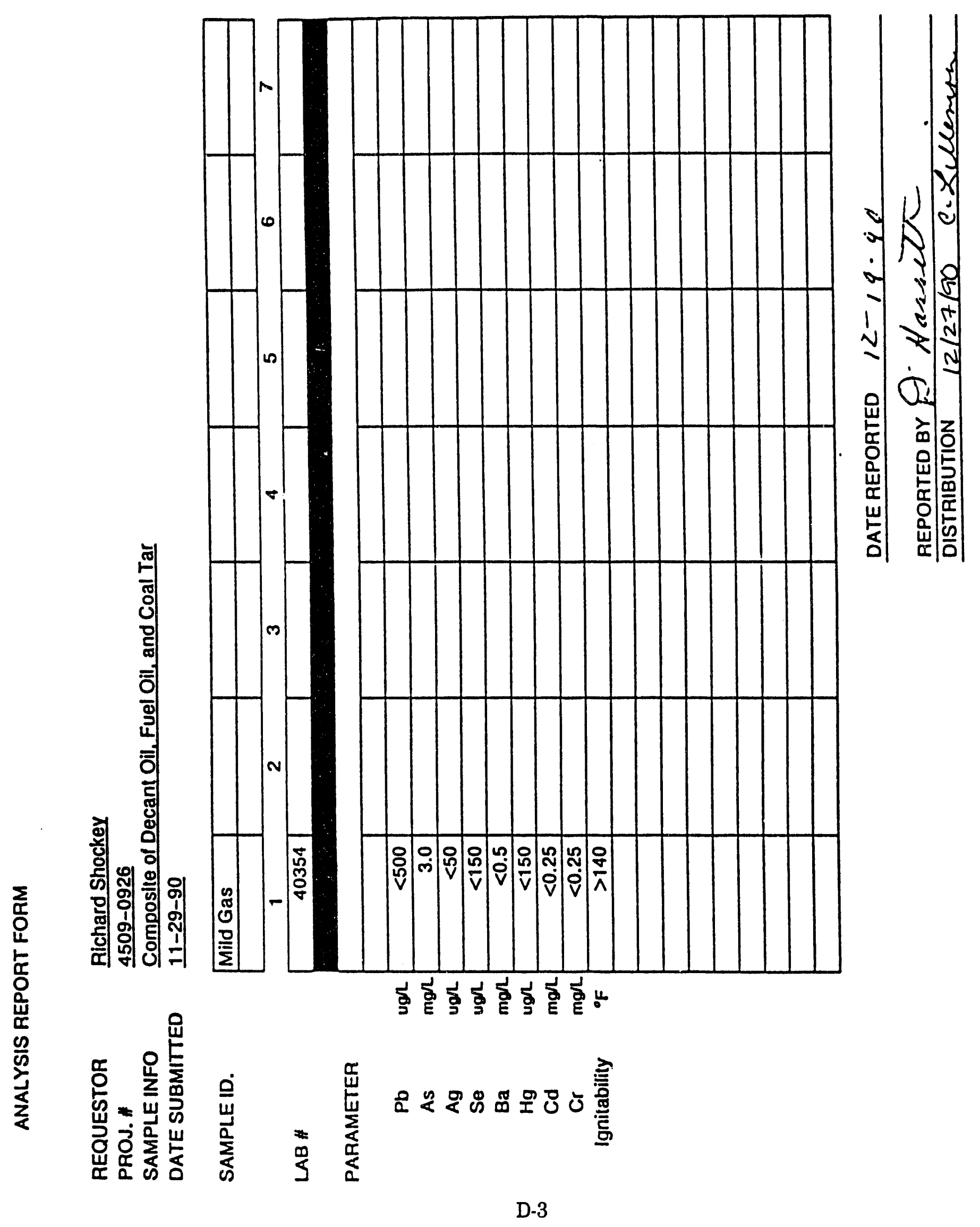


APPENDIX E

ESTIMATED COSTS ASSOCLATED WITH THE

DECOMMISSIONING OF THE CFBR AND PRU 
FILES: DISPOSAL

24-Sep- 92

DISPOSAL

$24-\operatorname{sep}-92$

$04: 12 \mathrm{PM}$

$\begin{array}{ll}\text { LABOR } & \text { LABOR CATEGORY } \\ \text { W. HILLSON } & \text { INSTITUTE RGR. } \\ \text { J. HENDRIKSON } & \text { FACILITY MANAGER } \\ \text { R. NESS } & \text { RES. SCIENTIST III } \\ \text { R. SHOCKEY } & \text { RES. SCIENTIST II } \\ \text { B. RUNGE } & \text { RES. SCIENTIST I } \\ \text { OPERATORS } & \text { PILOT PLANT OP. III } \\ \text { INSTRUMENT SHOP } \\ \text { CLERICAL/GRAPHICS } \\ \\ \text { SUBTOTAL } \\ \text { SALARY ESCALATION }\end{array}$

FRINGE BENEFITS AS $\approx$ OF DIRECT LABOR

TOTAL LABOR CHARGES

OTHER DIRECT CHARGES

TRAVEL

OPERATING SUPPLIES

FEES

SECRETARIAL SERVICES

ELECTRICIANS

SHOP/OPERATOR SUPPORT CHARGE WASTE DISPOSAL

TOTAL FEES

TOTAL OTHER DIRECT COST (OOC)

TOTAL OIRECT $=$ LABOR BASED + ODC

IHDIRECT COST AS $\%$ MTDC

EQUIPMENT COSTING $>\$ 500$

TOTAL ESTIMATED COST

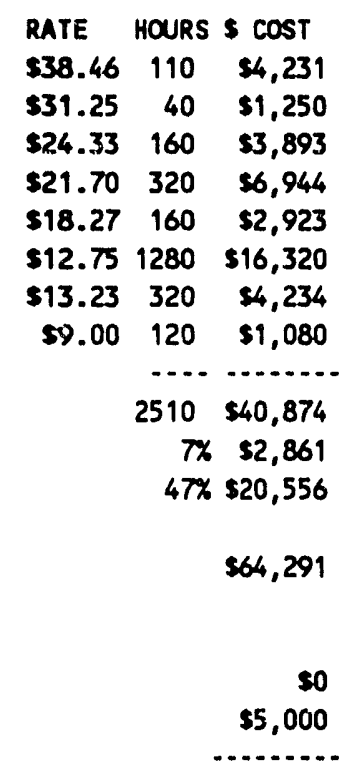

$\$ 763$

$\$ 3,500$

$\$ 1,088$

$\$ 7,500$

$\$ 12,851$

..........

$\$ 17,851$

$\$ 82,142$

$42 X \quad \$ 34,499$

50

116,641 

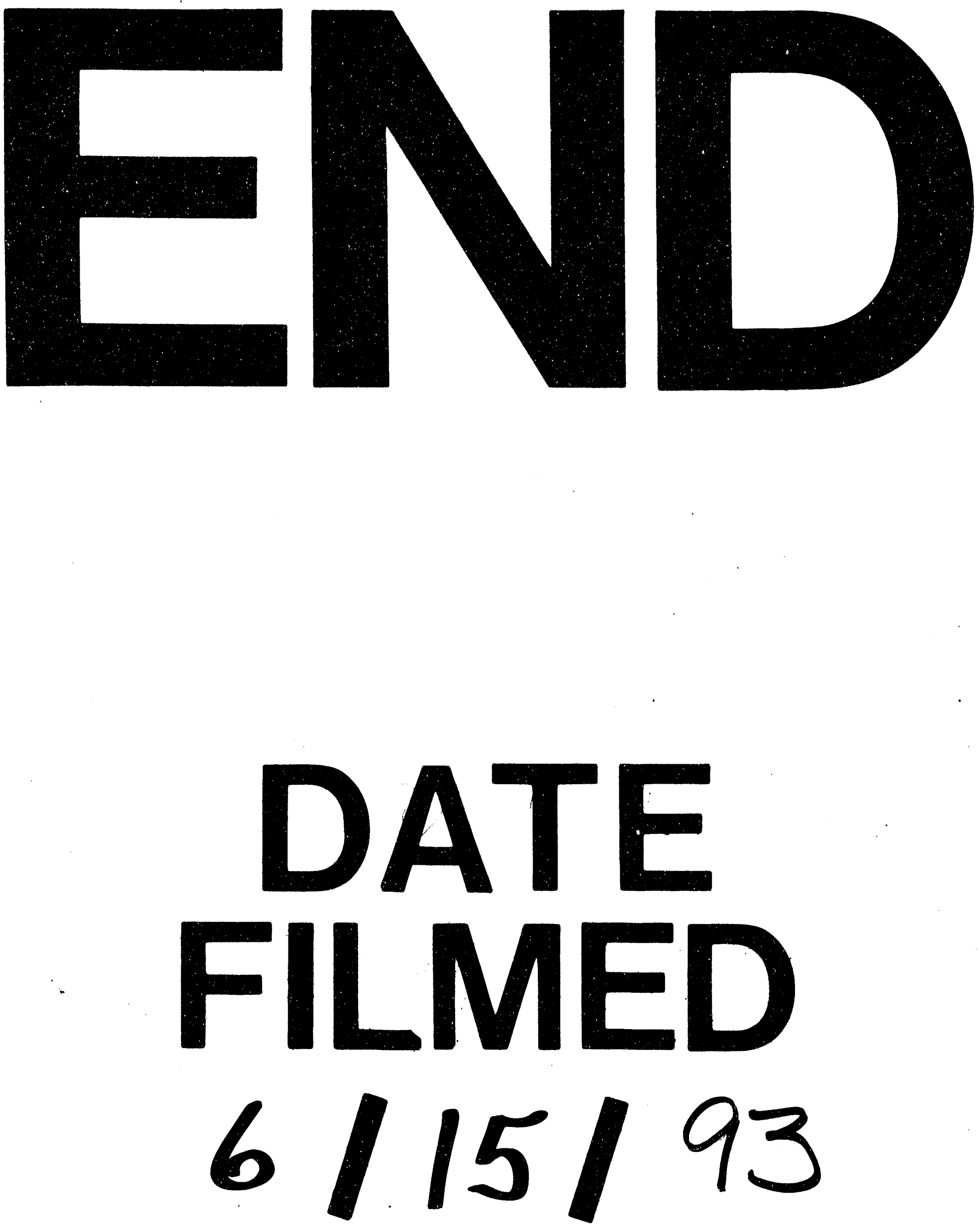
